\title{
Detection of potentially hazardous convective clouds with a dual-polarized C-band radar
}

\author{
A. Adachi ${ }^{1}$, T. Kobayashi ${ }^{1,2}$, H. Yamauchi ${ }^{1}$, and S. Onogi ${ }^{1}$ \\ ${ }^{1}$ Meteorological Research Institute, 1-1 Nagamine, Tsukuba 305-0052, Japan \\ ${ }^{2}$ Central Research Institute of Electric Power Industry, 1646 Abiko, Abiko-city 270-1194, Japan
}

Correspondence to: A. Adachi (aadachi@mri-jma.go.jp)

Received: 15 March 2013 - Published in Atmos. Meas. Tech. Discuss.: 15 April 2013

Revised: 9 August 2013 - Accepted: 10 September 2013 - Published: 21 October 2013

\begin{abstract}
A method for forecasting very short-term rainfall to detect potentially hazardous convective cloud that produces heavy local rainfall was developed using actual volumetric C-band polarimetric radar data. Because the rainfall estimation algorithm used in this method removed the effect of ice particles based on polarimetric measurements, it was immune to the high reflectivity associated with hail. The reliability of the algorithm was confirmed by comparing the rainfall rate estimated from the polarimetric radar measurements at the lowest elevation angle with that obtained from optical disdrometers on the ground. The rainfall rate estimated from polarimetric data agreed well with the results obtained from the disdrometers, and was much more reliable than results derived from reflectivity alone.

Two small cumulus cells were analyzed, one of which developed and later produced heavy rainfall, whereas the other did not. Observations made by polarimetric radar with a volumetric scan revealed that a high vertical maximum intensity of rainfall rate and a vertical area of enhanced differential reflectivity extending above the freezing level, often termed a high $Z_{\mathrm{DR}}$ column, were clearly formed about $10 \mathrm{~min}$ prior to the onset of heavy rainfall on the ground. The onset time of the heavy rainfall could be estimated in advance from the polarimetric data, which agreed fairly well with observations. These polarimetric characteristics were not observed for the cumulus cell that did not produce heavy rainfall. The results suggest that both the vertical maximum intensity of the rainfall rate and a high $Z_{\mathrm{DR}}$ column, estimated from polarimetric measurements, can be used to identify potentially hazardous clouds. Furthermore, this study shows that polarimetric radar measurements with high spatial and temporal resolutions are invaluable for disaster reduction.
\end{abstract}

\section{Introduction}

Heavy convective rainfalls, in conjunction with accompanying phenomena such as rainstorms, hail, and flash flooding, have an immediate and often devastating impact on a broad range of human activities, especially in urban areas. Due to the material damage and loss of life associated with such events, a number of research projects have been initiated to study the meteorological causes and hydrological effects of rainfall events associated with flash floods (e.g. Maki et al., 2012; Chandrasekar and Philips, 2012; Borga et al., 2011). One of the main challenges posed by flash floods is the extremely rapid response time of many of catchments, which can be as short as 10 min for small urban watersheds in mountainous environments (Brauer et al., 2011). An extension of several minutes' lead time could improve very shortterm forecasting (nowcasting) and allow for early warnings of heavy rain and flash flooding, thereby mitigating most of the damage and loss of life.

The requirement for short response times makes rainfall nowcasts from radar-based short-term precipitation forecasting more valuable than numerical weather prediction for issuing operational early warning services. Numerical models, including the radar-data assimilation method (Kawabata et al., 2011 and references therein), remain unsuitable for hydrological needs in terms of the necessary spatial and temporal resolution and in terms of the computation time for the small space and timescales that correspond to flash floods (e.g. Boudevillain et al., 2006; Liguori and Rico-Ramirez, 2012). 
Radar-based short-term precipitation forecasting has been addressed by various approaches. Rainfall estimation using radar has traditionally been accomplished by relating the reflectivity factor $\left(Z_{\mathrm{H}}\right)$ to the rainfall rate through a so-called $Z-R$ (hereafter $R\left(Z_{\mathrm{H}}\right)$ ) relation. The widely used methods are based on advection, and they extrapolate the propagation of rain regions derived from radar echoes (e.g. Li et al., 1995). Ruzanski and Chandrasekar (2012) suggested that radar-based advection methods in Lagrangian space are useful for up to about $20 \mathrm{~min}$ for precipitation patterns even at the microalpha $(0.2-2 \mathrm{~km})$ scale. Some methods track the displacement of individual rain cells and extrapolate their velocity, whereas others use characteristics such as shape, intensity, and size (Johnson et al., 1998; Lakshmanan et al., 2006; Ruzanski et al., 2011). Additionally, Seed (2005) broke the rainfall pattern into a series of patterns of different-sized areas of rain, treating each area separately. The performance of these methods, however, depends on the precipitation type, with much better results for stratiform than for convective rain (e.g. Wilson et al., 2004), despite heavy rainfall occurring more often from the latter (Boudevillain et al., 2006).

The lesser success in predicting convective rain is because most radar-based advection methods do not take the vertical advection of rain into account despite the rapid vertical development of convective clouds. Requirements for the estimation of vertical advection may include vertical profiles of the terminal velocity of raindrops, drop-size distribution (DSD), and/or rainfall rate, although all of these terms may change with time because of the nature of raindrops, including break up and collision (e.g. Rutledge and Hobbs, 1984; Kobayashi and Adachi, 2001). By assuming a realistic vertical profile of DSD, Boudevillain and Andrieu (2003) estimated the accuracy of vertically integrated liquid water content (hereafter referred to as VIL) for radar measurements.

VIL represents the atmospheric water content that can be deduced from volumetric scanning of the reflectivity field measured by classical weather radars, and it indicates the precipitation water content (Greene and Clark, 1972). VIL has been used mainly for severe storm warning and quantitative rainfall forecasting (e.g. Lakshmanan et al., 2006). Boudevillain et al. (2006) evaluated very short-term rainfall forecast models by considering vertical advection based on VIL using actual radar data. Their results demonstrated that although VIL could improve advection rainfall forecasting methods, the performance was still insufficient for practical applications. This could be because of the low reliability of $R\left(Z_{\mathrm{H}}\right)$ methods, especially for convective rainfalls, on which VIL is based. Other reasons may include the inability of classical radars to discriminate ice precipitation from liquid precipitation in the reflectivity field and consequent large errors in the retrieval of quantitative rainfall forecasting using VIL, despite the fact that ice precipitation is often associated with heavy rainfall. Radars with dual-polarized capability could, however, mitigate the effect of ice particles and obtain better rainfall estimations.
The efficacy of dual-polarization radar for quantitative precipitation estimation (QPE) has been demonstrated in a number of previous studies (see Bringi and Chandrasekar, 2001 for a review). These studies have shown that rainfall retrieval using combinations of polarimetric variables have an advantage over traditional $R\left(Z_{\mathrm{H}}\right)$ methods because more information regarding DSD is available (e.g. Anagnostou et al., 2004). Furthermore, dual-polarization-based rainfall rate estimators can better account for the presence of ice in the sampling volume (e.g. Golestani et al., 1989; Cifelli et al., 2011). The quality of the retrieved rainfall rate, however, strongly depends on the reliability of the polarimetric parameters obtained by the radar (Illingworth and Blackman, 2002). One of the disadvantages of polarimetric measurements is that it often needs more samplings $(\sim 100)$ than does classical radar $(\sim 30)$ to observe polarimetric data with sufficiently high precision, which results in relatively low temporal resolution (Bringi and Chandrasekar, 2001; Sachidananda and Zrnić, 1985, 1987). However, Illingworth (2004) pointed out that if polarization techniques require longer dwell times, the poor sampling could negate any increased accuracy of specific rainfall estimates. Knight (2006) also noted that time resolution is a critical factor in studies designed to better understand the early formation of precipitation in cumulus.

For rapid updates, some radars do not make volumetric scans but restrict polarimetric measurements at low elevation angles. This observation method is suitable for QPE on the ground. Additionally, the fact that the magnitude of most polarimetric variables decreases with the antenna elevation angle may also promote this elevation restriction. However, a volumetric scan is essential for very short-term forecasts to obtain information regarding the vertical characteristics of convective clouds that produce heavy precipitation. Moreover, a high time resolution is required to determine the evolution of convective clouds at the development (cumulus) stage because the duration of this stage is between 10 and $15 \mathrm{~min}$ in radar observation (Byers and Braham, 1949). Kumjian et al. (2010) used sector scans to increase the time resolution of polarimetric measurements for convective clouds but needed to restrict the size of the observation area.

The practical time resolution and thus the reliability of polarimetric measurements can be determined by the co-polar correlation coefficient at zero lag $\left(\rho_{\mathrm{HV}}(0)\right)$ in rain (Bringi and Chandrasekar, 2001). Sachidananda and Zrnić (1985) showed that reliable polarimetric data can be obtained from 50 simultaneous samples when $\rho_{\mathrm{HV}}(0)>0.995$ and the spectrum width $>4 \mathrm{~m} \mathrm{~s}^{-1}$. The value of $\rho_{\mathrm{HV}}(0)$ measured with polarimetric radars has been increasing with the advent of innovative radar technology. Gourley et al. (2006) reported $\rho_{\mathrm{HV}}(0)$ peak values in rain better than 0.99 for the Trappes radar with a sample number of 23 and a time resolution of $15 \mathrm{~min}$. More recently, Yamauchi et al. (2012) reported $\rho_{\mathrm{HV}}(0)$ peak values of 0.998 , which implies the use of a surprisingly reliable radar, as this value is very close to the theoretical expectation of 0.999 for drops without oscillation 
(Sachidananda and Zrnić, 1985). Additionally, they recorded this peak value with a sample number of 20 , which enabled volumetric scans with a time resolution of 4 minutes for their system. Thus, this radar may have the capability to investigate the evolution of cloud in the development stage, as is required for very short-term forecasts. In this study, we propose an approach to diagnose and detect potentially hazardous convective cloud for very short-term forecasting with rapid-scanning polarimetric radar.

This paper is organized as follows. In Sect. 2 we describe the instruments and methodology used in the study. The reliability of the method is confirmed by comparing estimations with disdrometer measurements. In Sect. 3, we present an overview of the evolution of two convective clouds, one of which produced heavy rainfall, whereas the other did not. In Sect. 4, we diagnose convective clouds by analyzing the evolution of the vertical structure, including polarimetric variables, and demonstrate the ability to detect potentially hazardous convective cloud with rapid-scan polarimetric radar.

\section{Instrumentation and data analysis techniques}

\subsection{MRI C-band polarimetric radar}

The Meteorological Research Institute (MRI) advanced Cband solid-state polarmetric radar (MACS-POL radar) was installed at the MRI in 2008 and mounted on top of the MRI building in Tsukuba, Japan. The operating system including transmitters and receivers is located under the floor of the building's radome to reduce signal loss. The radar routinely collects a full suite of dual-polarization measurements, including the reflectivity factor $\left(Z_{\mathrm{H}}\right)$, differential reflectivity $\left(Z_{\mathrm{DR}}\right)$, differential propagation phase $\left(\Psi_{\mathrm{DP}}\right)$, and correlation coefficient at zero lag $\left(\rho_{\mathrm{HV}}(0)\right)$. The configuration and operating parameters of the radar are summarized in Table 1. The precision of observation is enhanced by several standard measurements including transmitter and receiver calibration. The radar system was calibrated from data collected during weak stratiform rain by use of an auto-calibration technique (Gourley et al., 2009; Illingworth, 2004; Goddard et al., 1994) assuming a modified gamma distribution of raindrops with the axis ratio proposed by Brandes et al. (2002, 2005). Vertical measurement in rain was used to calibrate the $Z_{\mathrm{DR}}$ measurement (Illingworth, 2004). Through the adoption of these calibration procedures, the uncertainty in the individual range gate $Z_{\mathrm{H}}\left(Z_{\mathrm{DR}}\right)$ values was considered to be less than $0.5 \mathrm{~dB}(0.1 \mathrm{~dB})$.

This system employs two solid-sate amplifier units to transmit horizontally and vertically polarized waves. Because the peak power of the amplifiers was slightly weak, observations were made with a long pulse to increase the mean power. A pulse compression technique with a linear FM chirp was used to increase range resolution. The range side lobe associated with this technique was suppressed to

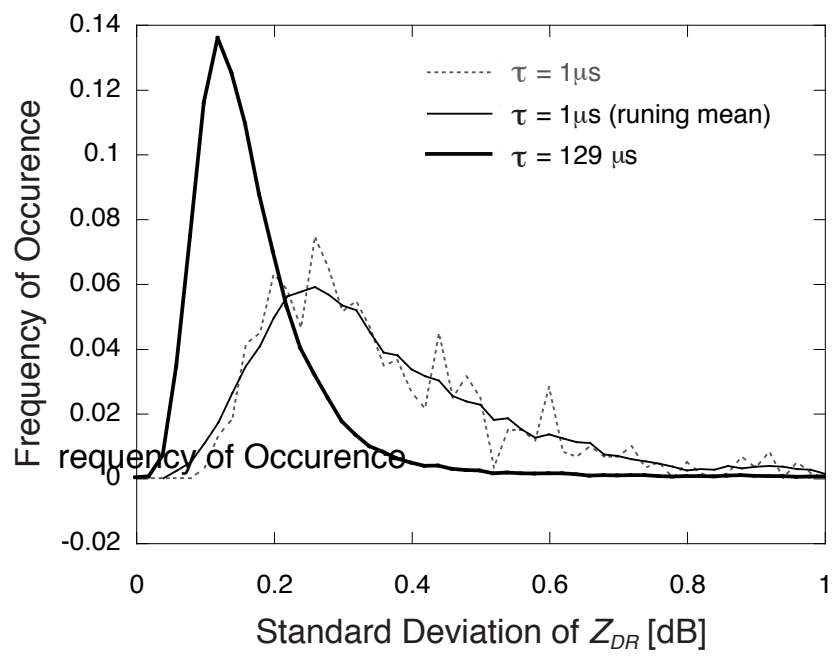

Fig. 1. Distribution of the standard deviation of differential reflectivity $\left(Z_{\mathrm{DR}}\right)$ for samples collected in stratiform rain by the MRI C-band polarimetric radar. Signals greater than or equal to the signal minimum level $+20 \mathrm{dBm}$ were used. The peaks measured were $0.26 \mathrm{~dB}$ for short-pulse observations $(\tau=1 \mu \mathrm{s})$ and $0.12 \mathrm{~dB}$ for longpulse observations ( $\tau=129 \mu$ s), respectively.

less than $-48 \mathrm{~dB}$ (Yamauchi et al., 2012). Because radar cannot observe in the vicinity of the antenna in the range of a long-pulse length, this radar alternatively transmitted a short and long pulse to cover the blind region associated with the long-pulse observation. The operating frequencies deployed for the two pulses were separated to avoid mutual contamination.

The radar is equipped with two receiving channels, which have nearly identical waveguide runs and operate in parallel, thus enabling the simultaneous transmission and reception (STAR) mode of polarized signals. Sachidananda and Zrnić (1985) showed that the precision of differential reflectivity $\left(Z_{\mathrm{DR}}\right)$ and the differential phase $\left(\Psi_{\mathrm{DP}}\right)$ measured with this mode are higher than that of an alternative transmission scheme when the $\rho_{\mathrm{HV}}(0)$ is very high $(>0.995)$ and/or the sampling number is small. Yamauchi et al. (2012) reported that this radar has peak $\rho_{\mathrm{HV}}(0)$ values of 0.992 for shortpulse and 0.998 for long-pulse observations, respectively, with a sample number of 20 deploying the STAR mode in stratiform rain. Using the measured peak value of $\rho_{\mathrm{HV}}(0)$ and sample number of 20 , the theoretical measurement errors for $Z_{\mathrm{DR}}$ obtained in the STAR mode were estimated to be less than $0.2 \mathrm{~dB}$ for the short-pulse and $0.1 \mathrm{~dB}$ for the longpulse observations, respectively, when the spectrum width was $4 \mathrm{~m} \mathrm{~s}^{-1}$ (Bringi and Chandrasekar, 2001).

Figure 1 displays the distributions of the standard deviation of $Z_{\mathrm{DR}}$ measured in stratiform rain by the MACS-POL radar with a sample number of 20 . An altitude threshold was imposed to restrict sampling to only liquid hydrometeors below the bright band. The data set was limited to data associated with a $\Psi_{\mathrm{DP}}$ less than $10^{\circ}$ to avoid bias by 
Table 1. Operating characteristics of the MRI C-band polarimetric radar.

\begin{tabular}{|c|c|}
\hline Frequency & $5370 \mathrm{MHz}$ \\
\hline Occupied band width & $<4.5 \mathrm{MHz}$ \\
\hline Peak power & $3.5 \mathrm{~kW}$ (for each channel, simultaneous transmission) \\
\hline Duty & $20 \%(\operatorname{Max})$ \\
\hline Pulse length & $\begin{array}{l}1 \mu \mathrm{s}(\text { range }<20 \mathrm{~km}) \text { and } 129 \mu \mathrm{s}(\geq 20 \mathrm{~km}) \text { for Elv. }<8^{\circ} \\
1 \mu \mathrm{s}(\text { range }<7.5 \mathrm{~km}) \text { and } 47 \mu \mathrm{s}(\geq 7.5 \mathrm{~km}) \text { for Elv. } \geq 8^{\circ}\end{array}$ \\
\hline Pulse compression & Linear FM chirp for long-pulse observations \\
\hline Antenna diameter & Parabolic dish, $\Phi=4 \mathrm{~m}$ \\
\hline Antenna speed & $4 \mathrm{rpm}$ for Elv. $<8^{\circ}$ and $6 \mathrm{rpm}$ for Elv. $\geq 8^{\circ}$ (10 rpm Max.) \\
\hline Signal minimum & $<-110 \mathrm{dBm}$ \\
\hline Antenna gain $(H$ and $V)$ & $>42 \mathrm{dBi}$ \\
\hline Max cross-polar isolation & $<-40 \mathrm{~dB}$ \\
\hline Beam width & $1.01^{\circ}$ \\
\hline Azimuth spacing & $0.7^{\circ}$ \\
\hline Transmitter & GaAs Power FET \\
\hline Number of linear sampling & 20 \\
\hline Range gate spacing & $150 \mathrm{~m}$ \\
\hline PRF & $624 / 780 \mathrm{~Hz}\left(\right.$ Elv. $\left.<8^{\circ}\right)$ and $936 / 1170 \mathrm{~Hz}\left(\right.$ Elv. $\left.\geq 8^{\circ}\right)$ \\
\hline Observation parameters & $Z_{\mathrm{H}}, Z_{\mathrm{V}}, Z_{\mathrm{DR}}$, radial velocity, $\rho_{\mathrm{HV}}(0)$ and $\Psi_{\mathrm{DP}}$ \\
\hline Manufacture & TOSHIBA \\
\hline
\end{tabular}

attenuation. Additionally, data at least $20 \mathrm{~dB}$ larger than the signal minimum level was used. Nine-gate windows along a radial were used to compute the standard deviation based on the analysis proposed by Sugier et al. (2006).

Figure 1 indicates that the standard deviation of $Z_{\mathrm{DR}}$ measured with the MACS-POL radar has a peak value of $0.12 \mathrm{~dB}$ $(0.26 \mathrm{~dB})$, with more than $76 \%(19 \%)$ of observations less than or equal to $0.2 \mathrm{~dB}$ for long (short) pulses, which is consistent with theoretical values. This suggests that the quality of the $Z_{\mathrm{DR}}$ measured with this radar is suitable for reliable quantitative precipitation estimates (QPE), especially for the long-pulse observations, even with a sample number of 20 , because rainfall rates greater than $10 \mathrm{~mm} \mathrm{~h}^{-1}$ can be estimated with an accuracy of $25 \%$ if the $Z_{\mathrm{DR}}$ measurement error is less than $0.2 \mathrm{~dB}$ (e.g. Illingworth, 2004; Illingworth and Blackman, 2002). The sample number of 20 corresponds to an antenna rotation speed of $4 \mathrm{rpm}$ for observations with elevation angles less than $8^{\circ}$ and 6 rpm for elevation angles greater than $8^{\circ}$ for the MACS-POL radar with the operating parameters shown in Table 1. This rotation speed sequence of the antenna enables the temporal resolution of the volumetric scans with this system in 4 min with 15 elevation observations.

The scan elevation sequence was $0.5,1.0,1.5,2.1,2.8$, $3.6,4.8,0.5,6.2,8.0,10.4,14.0,18.0,23.0$ and $30.0^{\circ}$. Two observations at an elevation angle of $0.5^{\circ}$ were made in the sequence to increase the time resolution near the ground, but only the first one is used in the analyses of cross sections in Sect. 4.1 and the vertical maximum intensity of the rainfall rate in Sect. 4.2. Volumetric scans of polarimetric parameters enable investigation of the evolution of rainfall rate near the ground and in the atmosphere. We used the vertical profile of the rainfall rate to detect potentially hazardous clouds that produce heavy rainfall, as shown later. The method used to estimate the rainfall rate from polarimetric parameters and its reliability are described in the next section. The reliability of the method was confirmed by comparing the estimated rainfall rate from the radar at the lowest elevation angle with that measured by optical disdrometers (Parsivel) on the ground. In Appendix A, we evaluate the Parsivel measurements by comparing them with a co-located weighing rain gauge and propose a method to increase the reliability of the Parsivel measurements. Effects of ice precipitation on the estimation of rainfall rate are discussed in Appendix B.

\subsection{Description of the data analysis technique}

In polarimetric weather radar systems, relationships between polarization variables and rainfall of the form $R\left(Z_{\mathrm{H}}\right), R\left(Z_{\mathrm{H}}\right.$, $\left.Z_{\mathrm{DR}}\right), R\left(K_{\mathrm{DP}}\right)$ and $R\left(K_{\mathrm{DP}}, Z_{\mathrm{DR}}\right)$, have been used to estimate the rainfall rate (see Bringi and Chandrasekar, 2001 for a review). However, the algorithm presented herein does not use $K_{\mathrm{DP}}$ but relies primarily on the $Z_{\mathrm{DR}}$ measurements to estimate the rainfall rate because $K_{\mathrm{DP}}$ is computed from estimations of a differential propagation phase, $\Phi_{\mathrm{DP}}$ in the radial direction, which can be noisy for small-scale convective cells with a low rainfall rate during the developmental stage with which we are concerned (e.g. Sachidananda and Zrnić, 1987; Chandrasekar et al., 1990; Brandes et al., 2004). Moreover, estimations of $\Phi_{\mathrm{DP}}$ from measurements of differential phase, $\Psi_{\text {DP }}$ at C-band can be unreliable in the presence of large raindrops because of the effect of the backscatter differential phase $\left(\delta_{\mathrm{co}}\right)$. In practice, it may be difficult even for advanced techniques including a FIR-based method (e.g. Hubbert and 
Bringi, 1995) to remove the effect of $\delta_{\text {co }}$ to analyze smallscale convective cells with a low rainfall rate.

The $Z_{\mathrm{DR}}$ measurement has another advantage for detecting active convective cells at the developmental stage. Convections at this stage are often associated with a vertical area of enhanced differential reflectivity (up to $4-6 \mathrm{~dB}$ ) with low reflectivity (usually $35-50 \mathrm{dBZ}$ ) above the ambient melting level, i.e. a $Z_{\mathrm{DR}}$ column, which is formed by a strong updraft (e.g. Brandes et al., 1995; Bringi et al., 1991; Loney et al., 2002; Scharfenberg et al., 2005; Conway and Zrnić, 1993). Enhanced $Z_{\mathrm{DR}}$ values and a low $Z$ imply the presence of oblate hydrometeors. Aircraft particle measurements have confirmed that the $Z_{\mathrm{DR}}$ column is characterized (dominated) by small numbers of large raindrops (Brandes et al., 1995). Radars that are operated in the C-band, such as the MACS-POL radar, may have an advantage in observing the $Z_{\mathrm{DR}}$ column because they are more sensitive to large raindrops $\left(D_{\mathrm{e}} \geq 5 \mathrm{~mm}\right)$ than are radars operating at other frequencies (X- and S-bands) due to the Mie scattering resonance effect (Fig. 2). The drops within any $Z_{\mathrm{DR}}$ column are either advected into an updraft from elsewhere below the $0{ }^{\circ} \mathrm{C}$ level or may grow in situ. The $Z_{\mathrm{DR}}$ columns are therefore good indicators of regions of updraft in any particular storm, and the farther above the $0^{\circ} \mathrm{C}$ level the column extends, the more vigorous the updraft becomes (Scharfenberg et al., 2005). Thus, the $Z_{\mathrm{DR}}$ column has been used to analyze severe storms including matricellular storms (Bringi et al., 1991), supercell storms (Loney et al., 2002), hailstorms (e.g. Conway and Zrnić, 1993; Hubbert et al., 1998), and tornados (e.g. Ryzhkov et al., 2005). The $Z_{\mathrm{DR}}$ column has the potential to be used to identify potentially hazardous clouds that generate local heavy rainfall.

In addition to $Z_{\mathrm{DR}}$, difference reflectivity $\left(Z_{\mathrm{DP}}\right)$, proposed by Golestani et al. (1989), is also used in this algorithm to estimate the reflectivity-weighted ice fraction observed in the radar volume. The reflectivity-weighted ice fraction is then used to remove the effect of ice particles and obtain the rainonly reflectivity (Bringi and Chandrasekar, 2001; Cifelli et al., 2011).

The difference reflectivity is defined as

$$
Z_{\mathrm{DP}}=10 \log _{10}\left(\zeta_{\mathrm{H}}-\zeta_{\mathrm{V}}\right)
$$

where $\zeta_{\mathrm{H}}$ and $\zeta_{\mathrm{V}}$ are linear reflectivities for horizontal and vertical polarization, respectively. The $Z_{\mathrm{DP}}$ is insensitive to ice because ice particles such as randomly oriented hail appear statistically isotropic $\left(\zeta_{\mathrm{H}}^{\mathrm{ice}} \approx \zeta_{\mathrm{V}}^{\mathrm{ice}}\right.$ ) (Bringi and Chandrasekar, 2001). It is highly correlated with the rain-only reflectivity, being sensitive only to the oriented oblate rain$\operatorname{drops}\left(\zeta_{\mathrm{H}}^{\text {rain }}>\zeta_{\mathrm{V}}^{\text {rain }}\right)$, and so it is a good indicator of the presence of water within the rain-ice mixture. A rain line is developed by the regression of $Z_{\mathrm{H}}$ against $Z_{\mathrm{DP}}$ in precipitation regions that contain rain only. The rain line obtained is then applied in regions where ice particles may be included. The difference between the observed $Z_{\mathrm{H}}$ and the value expected

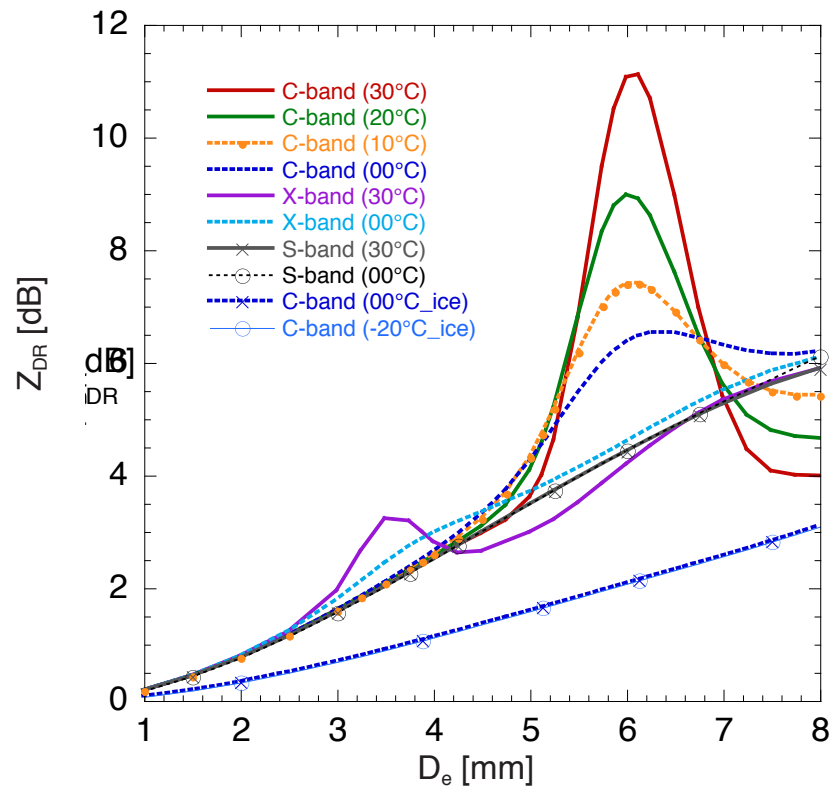

Fig. 2. Differential reflectivity $\left(Z_{\mathrm{DR}}\right)$ as a function of equivolumetric sphere diameter $\left(D_{\mathrm{e}}\right)$ at raindrop temperatures of 0 and $30^{\circ} \mathrm{C}$ at the S-band $(2.725 \mathrm{GHz}), \mathrm{C}$-band $(5.370 \mathrm{GHz})$, and $\mathrm{X}$-band $(9.375 \mathrm{GHz})$. Results for temperatures of 10 and $20^{\circ} \mathrm{C}$, and iced raindrops at 0 and $-20^{\circ} \mathrm{C}$ are also plotted for the C-band.

according to the rain line ( $\Delta Z$ in $\mathrm{dB})$ represents the amount of ice in the reflectivity according to

$f=\frac{\zeta^{\text {ice }}}{\zeta^{\text {rain }}}=1-10^{-0.1(\Delta Z)} ; \Delta Z \geq 0 \mathrm{~dB}$,

where $f$ is the ice fraction, and rain-only reflectivity at horizontal polarization can be obtained by

$\zeta_{\mathrm{H}}^{\mathrm{rain}}=(1-f) \zeta_{\mathrm{H}}$.

The rain line used in the present study was deduced from local convective heavy rainfall analyzed in this study at a mature stage, which is represented as

$Z_{\mathrm{DP}}=1.082 Z_{\mathrm{H}}^{\text {rain }}-7.089$,

with a correlation coefficient of 0.994 (Fig. 3). The statistical results, including the high correlation coefficient in the derivation of the rain-line, could reflect the reliability of the retrieval algorithm including the attenuation correction scheme described below.

The steps and sequence of equations used in the algorithm were as follows:

1. For each range profile (or beam) of data, a data mask was generated based on the standard deviation of $\Psi_{\mathrm{DP}}$ $\left(\leq 12^{\circ}\right)$ over seven consecutive gates, $\rho_{\mathrm{HV}}(\geq 0.85)$, and a signal to noise ratio ( $\mathrm{SNR} \geq 3 \mathrm{~dB}$ ) to remove non-meteorological data. 


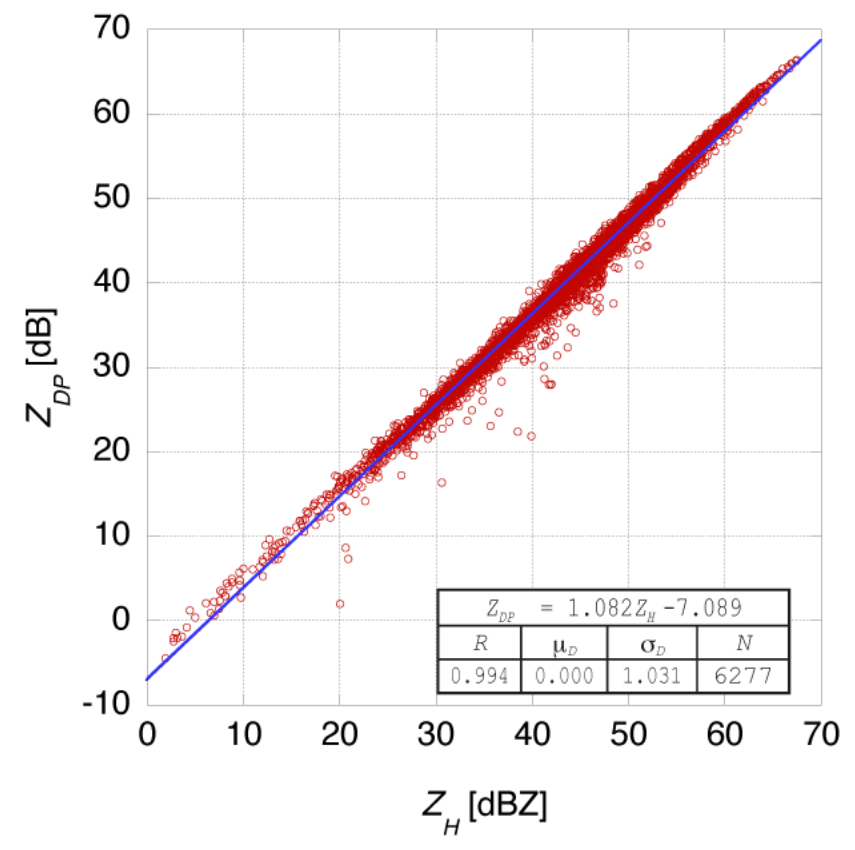

Fig. 3. Scatter plot of the reflectivity factor $\left(Z_{H}\right)$ vs. the difference reflectivity $\left(Z_{\mathrm{DP}}\right)$ measured in precipitation regions that contain rain only at the altitudes between $500 \mathrm{~m}$ and $4500 \mathrm{~m}$ a.g.l. at 03:23 JST on 7 July 2010. The line represents a linear regression (rain line) as shown in the legend on the bottom with the correlation coefficient, bias, standard deviation and number of samples.

2. A five-gate running mean was applied to the filtered $\Psi_{\mathrm{DP}}$ in each ray to mitigate $\delta_{\mathrm{co}}$ and obtain $\Phi_{\mathrm{DP}}$.

3. Elevation corrections for the observed $Z_{\mathrm{DR}}$ and $\Phi_{\mathrm{DP}}$ were applied by use of T-matrix (Mishchenko and Travis, 1994) calculations based on observed DSD from the optical disdrometers (Fig. 4). Then, the attenuation corrections were made for the elevationcorrected $Z_{\mathrm{DR}}$ and observed $Z_{\mathrm{H}}$ with the elevationcorrected $\Phi_{\mathrm{DP}}$ using the method proposed by Jameson (1992), with the assumption of linear relationships between specific attenuation $\left(A_{\mathrm{H}}\right)$ and $K_{\mathrm{DP}}$ and between differential attenuation $\left(A_{\mathrm{DP}}\right)$ and $K_{\mathrm{DP}}$ (Bringi and Chandrasekar, 2001; Bringi et al., 1990).

The corrected $Z_{\mathrm{H}}$ at range $r$ is obtained from observed reflectivity and $\Phi_{\mathrm{DP}}$ as follows:

$$
\begin{gathered}
Z_{\mathrm{H}}(r)=Z_{\mathrm{H}}^{\mathrm{obs}}(r)+\frac{0.07268}{\operatorname{RF}\left(\Phi_{\mathrm{DP}}(\theta)\right)} \\
\left\{\Phi_{\mathrm{DP}}(r)-\Phi_{\mathrm{DP}}(0)\right\}
\end{gathered}
$$

where the system $\Phi_{\mathrm{DP}}(0)$ is set to $0^{\circ}$ with no loss of generality. RF represents a reduction factor (Fig. 4), which is a function of elevation angle $\theta$. Note that the reduction factor for $\Phi_{\mathrm{DP}}$ is the same with that for $K_{\mathrm{DP}}$ as long as the elevation angle is equal. In the derivation of RF, we assumed the raindrop temperature of $20^{\circ} \mathrm{C}$,

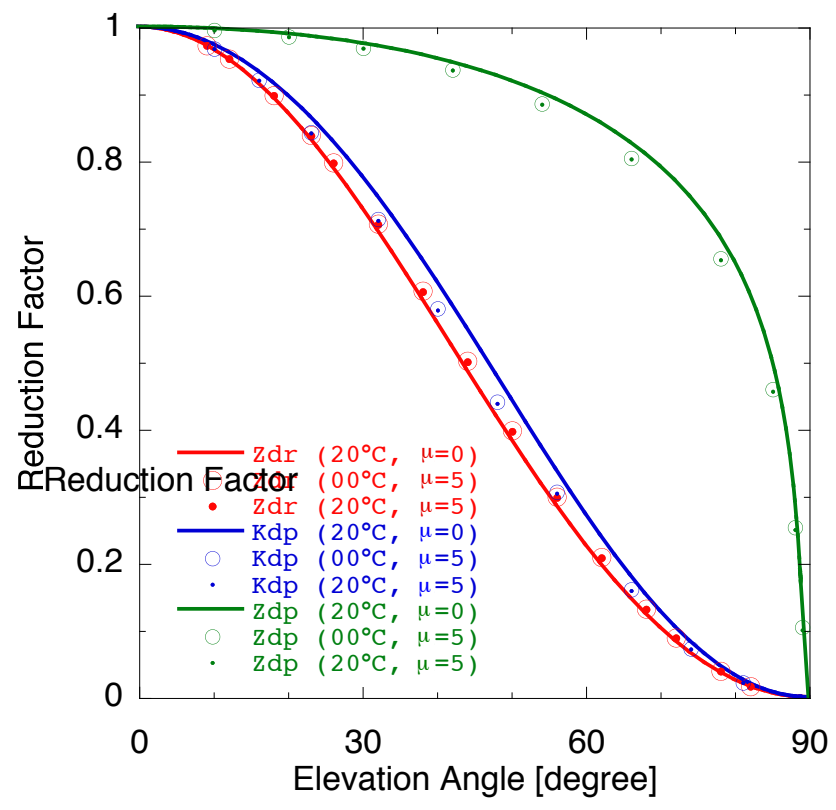

Fig. 4. Differential reflectivity $\left(Z_{\mathrm{DR}}\right)$, specific differential phase $\left(K_{\mathrm{DP}}\right)$ and difference reflectivity $\left(Z_{\mathrm{DP}}\right)$ as a function of elevation angle at raindrop temperatures of 0 and $20^{\circ} \mathrm{C}$ with shape parameters $(\mu)$ of 0 and 5 for a modified gamma distribution with an axis ratio of Brandes et al. (2002) and a median volume diameter $\left(D_{0}\right)$ of $2 \mathrm{~mm}$.

shape parameter $(\mu)$ of 5 and median diameter $\left(D_{0}\right)$ of $2 \mathrm{~mm}$. These values were determined from disdrometer measurements in heavy rain events on the ground, although RF has very low dependencies of temperature and $\mu$ (Fig. 4). Similarly, for $Z_{\mathrm{DR}}$

$$
\begin{aligned}
& Z_{\mathrm{DR}}(r)=\frac{Z_{\mathrm{DR}}^{\mathrm{obs}}(r)}{\operatorname{RF}\left(Z_{\mathrm{DR}}(\theta)\right)}+\frac{0.01331}{\operatorname{RF}\left(\Phi_{\mathrm{DP}}(\theta)\right)} \\
& \left\{\Phi_{\mathrm{DP}}(r)-\Phi_{\mathrm{DP}}(0)\right\} .
\end{aligned}
$$

The corrected $Z_{\mathrm{V}}$ is derived from $Z_{\mathrm{H}}$ and $Z_{\mathrm{DR}}$.

4. The difference reflectivity, $Z_{\mathrm{DP}}$, was derived from the corrected $Z_{\mathrm{H}}$ and $Z_{\mathrm{V}}$ using Eq. (1). The elevation angle dependency of $Z_{\mathrm{DP}}$ is quite small for low elevation angle observations (Fig. 4) but was considered in the algorithm. The ice fraction values were obtained from $Z_{\mathrm{DP}}$ using the $Z_{\mathrm{H}}$ data at more than $40 \mathrm{dBZ}$ $\left(\sim 12 \mathrm{~mm} \mathrm{~h}^{-1}\right)$ to avoid the effects of small spherical raindrops.

5. Rainfall rate $(R)$ was estimated using a method based on Gorgucci et al. (1994) but with parameters proposed by Bringi and Chandrasekar (2001) from the corrected $Z_{\mathrm{DR}}$ and $Z_{\mathrm{H}}$ data, with an ice fraction of less than 0.2 and a $Z_{\mathrm{DR}}$ greater than $0.5 \mathrm{~dB}$ as

$$
\begin{aligned}
& R\left(Z_{\mathrm{DR}}, Z_{\mathrm{H}}\right)=0.0058 \times 10^{0.091 Z_{\mathrm{H}}} \times 10^{-0.209 Z_{\mathrm{DR}}}, \\
& \quad \text { if } f<0.2 \text { and } Z_{\mathrm{DR}} \geq 0.5 \mathrm{~dB} .
\end{aligned}
$$


Note that an ice fraction of 0.2 corresponds to $\Delta Z$ of $1.0 \mathrm{~dB}$ in Eq. (2), which equals to the standard deviation of the rain line (Fig. 3).

6. In the case that the ice fraction was more than or equal to 0.2 or $Z_{\mathrm{DR}}$ was less than $0.5 \mathrm{~dB}$, the rainfall rate was derived from corrected $Z_{\mathrm{H}}$ values by using the $R\left(Z_{\mathrm{H}}\right)$ relationship (Hitschfeld and Bordan, 1954) defined as

$$
R\left(Z_{\mathrm{H}}\right)=\left(0.005 \times \zeta_{\mathrm{H}}\right)^{\frac{1}{1.6}},
$$

where

$$
\begin{aligned}
& \zeta_{\mathrm{H}}=10^{0.1 Z_{\mathrm{H}}}, \text { if } Z_{\mathrm{DR}}<0.5 \mathrm{~dB} \text { and } f<0.2 \text { or } \\
& \zeta_{\mathrm{H}}=10^{0.1 Z_{\mathrm{H}}}(1-f), \text { if } f \geq 0.2 .
\end{aligned}
$$

7. In the retrieval, additional quality control processes that were employed during the analysis rejected rainfall rate data exceeding $300 \mathrm{~mm} \mathrm{~h}^{-1}$ as outliers.

Although we estimated vertical profiles of rainfall rate with the algorithm mentioned above, the effect of air density on the raindrop fall speed (Foote and du Toit, 1969), which is one of the factors that determine rainfall rate aloft, was not taken into account because we considered the rainfall rate when the raindrops, particularly in the heavy rainfall region, reached the ground.

\subsection{Comparison with disdrometer}

To evaluate the reliability of the rainfall rate estimated using the method mentioned above, we compared the estimated rainfall rate with that observed by disdrometers (Parsivel) at Sekiyado and Kumagaya, which were located about 31.8 and $67.9 \mathrm{~km}$ west-northwest of the MRI site, respectively (Fig. 7). The accuracy of the Parsivel measurements is discussed in Appendix A. Comparisons were made using data recorded on 7 July 2012. The radar-estimated rainfall rate data available for the single point nearest to the Sekiyado or Kumagaya station were used for the comparisons. To compensate for the difference in observational heights (the radar beam center observed precipitation about $400 \mathrm{~m}(923 \mathrm{~m})$ above the Sekiyado (Kumagaya) station), the times of the radar measurements were adjusted to match with those of the Parsivel using the empirical terminal velocity (Gunn and Kinzer, 1949) of the median volume diameter $\left(D_{0}\right)$ of the raindrops observed with the Parsivels.

Time series of the rainfall rate derived from the Parsivel and the radar observations at Sekiyado (SYD) and Kumagaya (KMG) are shown in Fig. 5. The thick line shows the $1 \mathrm{~min}$ mean rainfall rate observed with the Parsivel, and the marks indicate the rainfall rate estimated every $2 \mathrm{~min}$ from $R\left(Z_{\mathrm{H}}\right.$, $Z_{\mathrm{DR}}$ ) using the methods proposed by Gorgucci et al. (1994) with parameters of Bringi and Chandrasekar (2001), Illingworth and Thompson (2005), and Zrnić et al. (2000) along
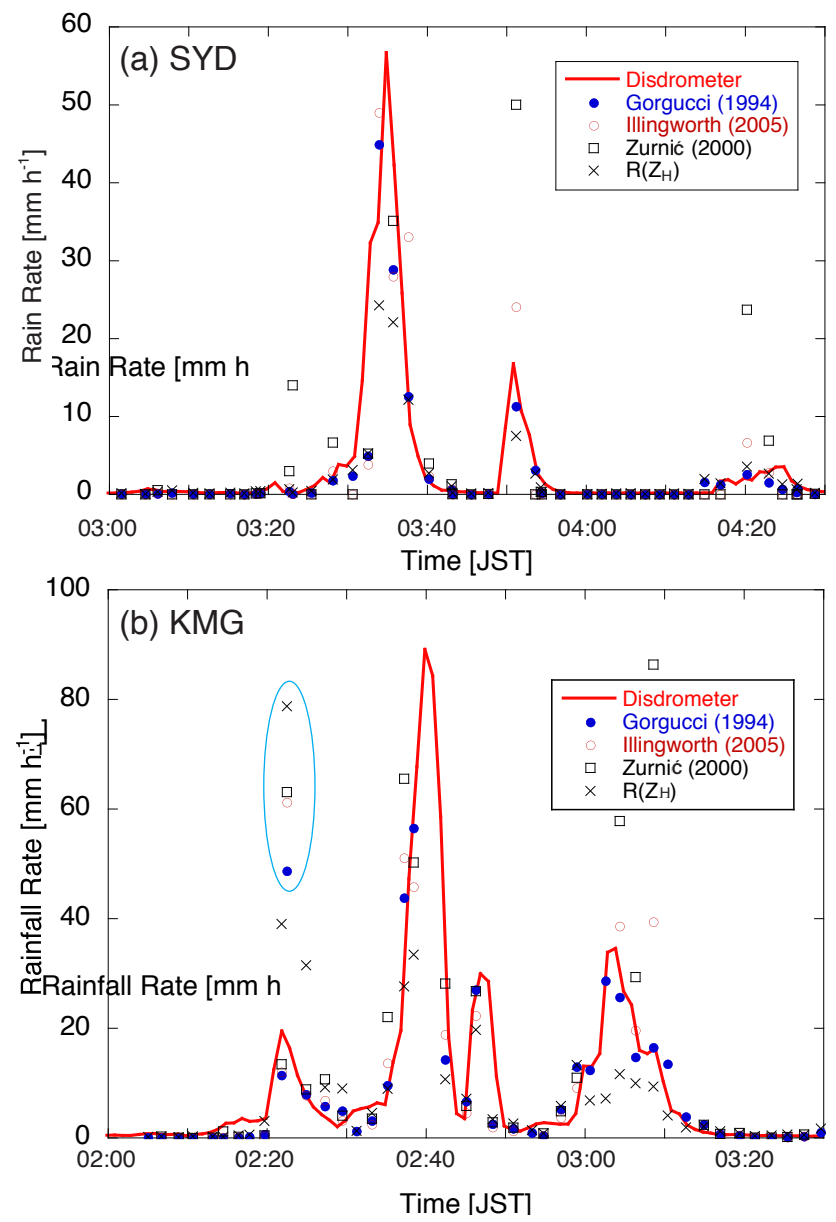

Fig. 5. Rainfall rate comparisons between disdrometer measurements (solid line) and MRI C-band polarimetric radar estimations using the $R\left(Z_{\mathrm{H}}, Z_{\mathrm{DR}}\right)$ method (circles and squares) and the $R\left(Z_{\mathrm{H}}\right)$ relationship (crosses) at (a) Sekiyado (SYD) and (b) Kumagaya (KMG) surface stations from 03:00 to 04:30 JST and from 02:00 to 03:30 JST on 7 July 2010, respectively. A blue ellipse in (b) surrounds outliers of rainfall rate estimated from the C-band radar at 02:22 JST.

with an estimation from the $R\left(Z_{\mathrm{H}}\right)$ relationship for reference. The algorithm described in Sect. 2.2 was used to derive $Z_{\mathrm{H}}$ and $Z_{\mathrm{DR}}$ for this comparison. The figure clearly shows that the three $R\left(Z_{\mathrm{H}}, Z_{\mathrm{DR}}\right)$ methods outperform the $R\left(Z_{\mathrm{H}}\right)$ relationship, particularly in heavy rainfall.

The radar data at 02:40 JST at Kumagaya was rejected because of low quality of the data. On the other hand, the large discrepancy at 02:22 JST was likely due to partially melted hydrometeors. The effects of ice particles in the retrieval of rainfall rate are discussed in appendix $\mathrm{B}$. Note that even at that time, the three $R\left(Z_{\mathrm{H}}, Z_{\mathrm{DR}}\right)$ methods outperformed the $R\left(Z_{\mathrm{H}}\right)$ relationship. A detailed error analysis (e.g. Thurai et al., 2012) documenting the various factors influencing the differences among the three methods is beyond the scope of this study. However, the consistency of $R\left(Z_{\mathrm{H}}, Z_{\mathrm{DR}}\right)$ with the 


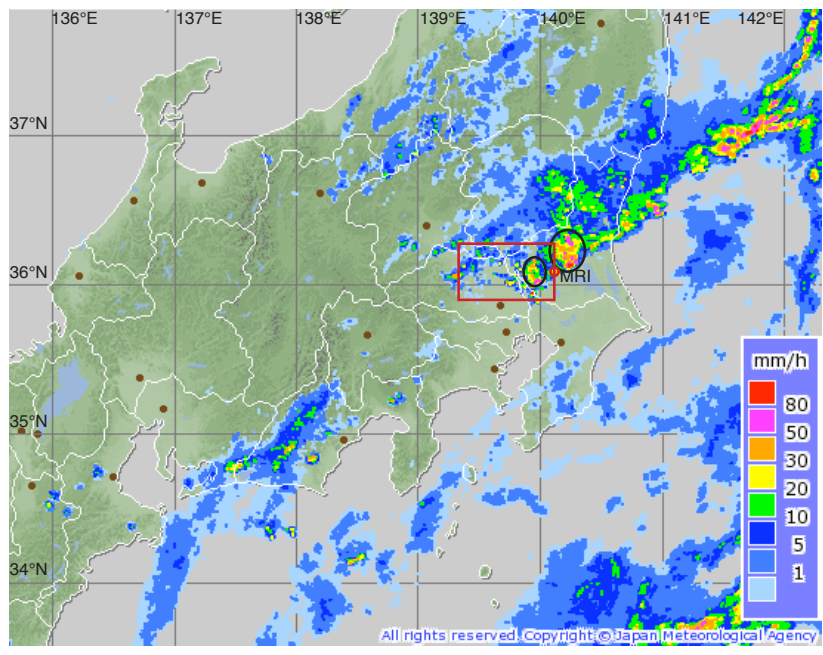

Fig. 6. Horizontal distributions of the rainfall rate at 04:00 JST on 7 July 2010 obtained from operational radar observations with the color scale on the bottom right. A rectangle depicts the analytical area in Fig. 7, and the red open circle on the right edge of the rectangle indicates the location of the MRI. Two black ovals surround heavy convective regions.

Parsivel measurements provides confidence that the method proposed by Gorgucci et al. (1994) is suitable for estimating rainfall rates for very short-term forecasting of localized heavy rainfall events. The data used in the comparison were actually recorded during a heavy local rainfall event, which is analyzed in the next section.

\section{Overview of a localized heavy rainfall event}

Horizontal distributions of the rainfall rate from the radar network operated by the Japan Meteorological Agency at 04:00 JST (Japan Standard Time: JST $=\mathrm{UTC}+9 \mathrm{~h}$ ) on 7 July 2010 are shown in Fig. 6. The radar-estimated rainfall rate was derived by use of a $R\left(Z_{\mathrm{H}}\right)$ relationship calibrated by rain gauge measurements of the Automated Meteorological Data Acquisition System (AMeDAS) operational surface observation network. In Fig. 6, black ovals surround the localized heavy convective rain regions at the mature stage, which are analyzed later, and a red rectangle indicates the region of this study, on the edge of which the MRI is located. The figure shows that the MRI was located between two convective rain regions, with a maximum rainfall rate exceeding $80 \mathrm{~mm} \mathrm{~h}^{-1}$ to the north at this time. The localized heavy rainfall continued until about 05:30 JST around the MRI. However, about $1 \mathrm{~h}$ prior to this heavy rainfall event, no definite echo was associated with localized heavy rainfall.

The radar reflectivity field observed by the MACS-POL radar at 02:53 JST indicates some convective cells around the MRI (Fig. 7). Most of the convective cells with reflectivity greater than $50 \mathrm{dBZ}$ were included in a large region of

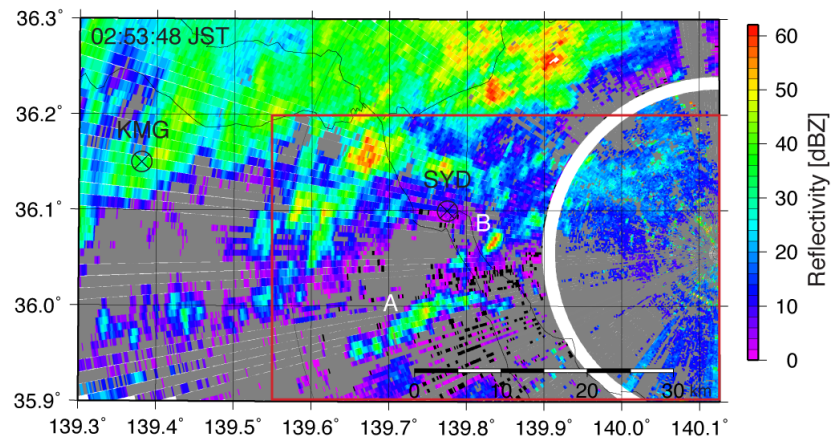

Fig. 7. Attenuation-corrected radar reflectivity field of the MRI Cband polarimetric radar at a $1.0^{\circ}$ elevation angle at 02:53 JST on 7 July 2010. The color scale represents radar reflectivity. $A$ and $B$ in the figure indicate convective cells, and the open circles with a cross indicate the locations of the Sekiyado (SYD) and Kumagaya (KMG) surface observation stations. The white circular band on the right, at $19-20.5 \mathrm{~km}$ from the radar, is a deficit region resulting from the alternation of short- and long-pulse observations; the red rectangle indicates the analytical area in Fig. 8.

rainfall expanding northwestwardly. However, at this stage, it is very difficult to predict from the figure which convective cell will develop most over time. Convective cell $B$, located ahead of the large region of rainfall, actually developed most, as shown later. We analyzed another convective cell $A$ for a reference because both cells were closely collocated and fairly comparable in size and intensity. The corresponding rainfall rate at this time is shown in Fig. 8a.

The evolution of the horizontal distribution of rainfall rate near the surface is indicated in Fig. 8a-d. The rainfall rate was estimated from the MACS-POL radar using the method described in Sect. 2.2. At 02:53 JST (Fig. 8a), the rainfall rates associated with both cells $A$ and $B$ were small in intensity and size (see Fig. 11 for detail). However, about $8 \mathrm{~min}$ later, the rainfall rate associated with $B$ exceeded $210 \mathrm{~mm} \mathrm{~h}^{-1}$ (Fig. 8b). This was the onset of the localized heavy rainfall (also see Fig. 14 for detail). From this point, cell $B$ developed more rapidly and its size expanded in a northeastward direction over time (Figs. 6 and 8b-d). At 03:29 JST, cell $B$ divided into two heavy rainfall regions, $B_{1}$ and $B_{2}$ (Fig. 8d), and the former was associated with the heavier rainfall. In contrast, cell A did not develop to a great extent despite its initial similarity in size and location to cell $B$. This result suggests that it is difficult in advance to distinguish with conventional weather radar between a convective cell that produces heavy rain and other cells in the reflectivity and/or rainfall rate fields with low elevation angle observations as previously mentioned because the horizontal distributions do not provide sufficient information regarding the progress of the rainfall. However, the vertical structure of the rainfall rate over the convective cells may allow potentially hazardous convective cells to be identified because the 

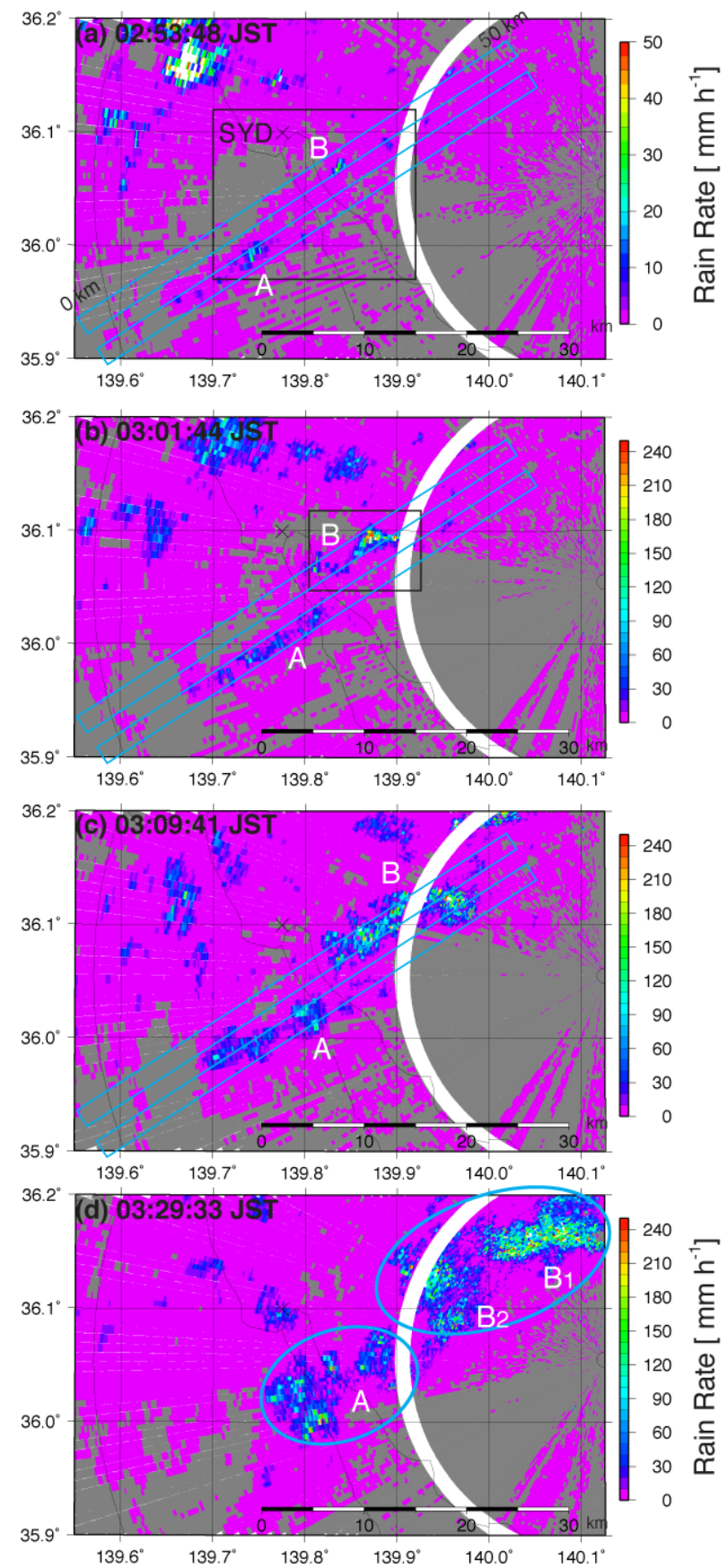

Fig. 8. MRI C-band radar rainfall rate estimation using differential reflectivity $R\left(Z_{\mathrm{H}}, Z_{\mathrm{DR}}\right)$ observed at a $1.0^{\circ}$ elevation angle at (a) 02:53 JST, (b) 03:01 JST, (c) 03:09 JST, and (d) 03:29 JST on 7 July 2010. The color scale represents the rainfall rate. $A$ and $B$ in the figure indicate convective rainfall cells. The cross symbol indicates the location of the Sekiyado (SYD) surface observation station. Blue rectangles representing a length of $50 \mathrm{~km}$ indicate the distance-height analytical areas in Figs. 9 and A2, and black rectangles in (a) and (b) indicate the analytical area in Figs. 10 and 11, and Figs. 12-14, respectively. Ellipses in (d) surround the matured $A$ and $B\left(B_{1}\right.$ and $\left.B_{2}\right)$.

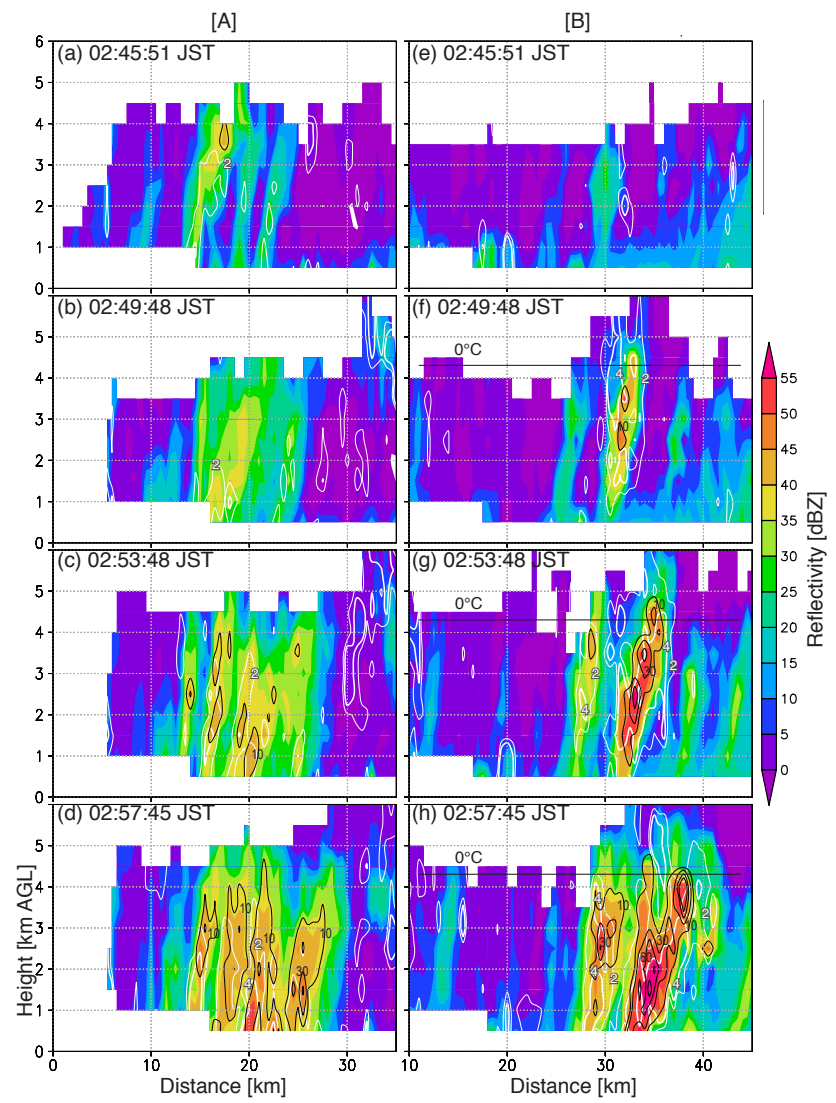

Fig. 9. Distance-height cross section of rainfall rate and differential reflectivity $\left(Z_{\mathrm{DR}}\right)$ superimposed over the attenuation-correctedrain-only reflectivity of $A(\mathbf{a}-\mathbf{d})$ and $B(\mathbf{e}-\mathbf{h})$ along the analytic area in Fig. 8. Black contours indicate estimated rainfall rates of 10, 30, 60 and $90 \mathrm{~mm} \mathrm{~h}^{-1}$, and white contours depict differential reflectivity at 2 and $4 \mathrm{~dB}$, respectively. The observation time is shown in the upper-left of each image.

heavy rainfall region could be formed aloft before the onset of the heavy rain on the ground.

\section{Vertical structures of the localized heavy rainfall}

\subsection{Distance-height cross section of the rainfall}

The evolution of the distance-height cross section of the rainonly reflectivity field along with the rainfall rate and differential reflectivity $\left(Z_{\mathrm{DR}}\right)$ obtained from the MACS-POL radar volumetric scans are shown in Fig. 9a-h. The reflectivity and differential reflectivity are linearly averaged in the figure. The figure covers a $16 \mathrm{~min}$ period just prior to the onset of heavy rainfall on the ground at 03:01 JST (Fig. 8b) at a time resolution of $4 \mathrm{~min}$. The freezing level was estimated to about $4.3 \mathrm{~km}$ a.g.l. (above ground level) from the bright band in the reflectivity field associated with stratiform rain located southwest of the radar site at that time (not shown). The bright band is a narrow horizontal layer of stronger radar 


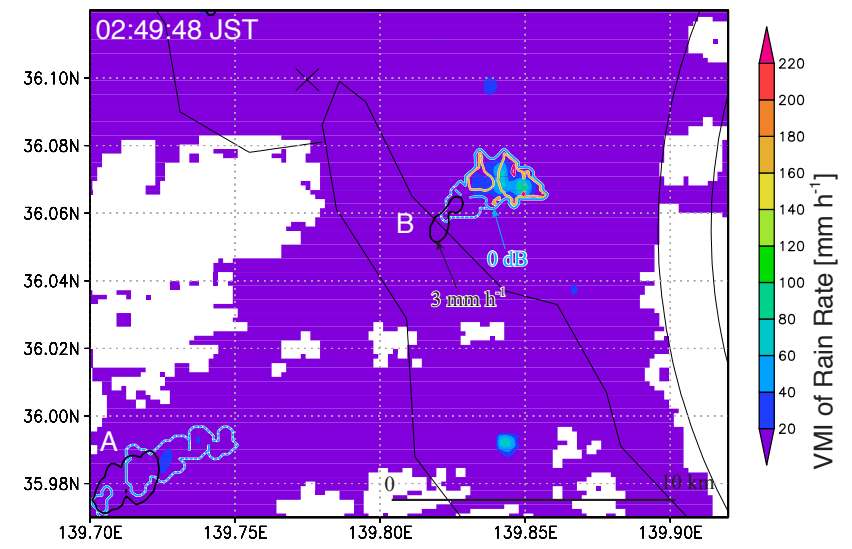

Fig. 10. Horizontal distribution of the vertical maximum intensity of differential reflectivity, $\operatorname{VMI}\left(Z_{\mathrm{DR}}\right)$, and the surface rainfall rate superimposed over the vertical maximum intensity of the rainfall rate, $\mathrm{VMI}(R)$, estimated from the MRI C-band polarimetric radar at 02:49 JST. Thick black contours indicate the surface rainfall rate at $3 \mathrm{~mm} \mathrm{~h}^{-1}$ and $18 \mathrm{~mm} \mathrm{~h}^{-1}$. Solid colored contours indicate $\operatorname{VMI}\left(Z_{\mathrm{DR}}\right)$ at altitudes above the freezing level from $0 \mathrm{~dB}$ with a contour interval of $3 \mathrm{~dB}$, and dashed-blue contours depict $\operatorname{VMI}\left(Z_{\mathrm{DR}}\right)$ located at altitudes less than the freezing level at $0 \mathrm{~dB}$. Partial circles on the right indicate the observation deficit region at an elevation angle of $0.5^{\circ}$ for reference.

reflectivity, primarily in stratiform precipitation at the level in the atmosphere where snow melts to form rain (Glickman, 2000). The bright band is usually centered about $100 \mathrm{~m}$ below the $0{ }^{\circ} \mathrm{C}$ isotherm (White et al., 2002). Note that the distance in the figure does not indicate the range from the radar site, as is shown in the so-called range-height indicator (RHI) observations, but the horizontal distance from the southwest ends of the $2 \mathrm{~km}$-wide rectangles indicated in Fig. 8, showing that both cells $A$ and $B$ were advected in the rectangles eastnortheastwardly at a mean speed of $10 \mathrm{~m} \mathrm{~s}^{-1}$. This advection may result in a shift of $1.6 \mathrm{~km}$ in distance at the $5 \mathrm{~km}$ altitude in each panel because of the observation time lag for beams with different elevation angles in the volume scans.

The reflectivity associated with cell $A$ increased over time (Fig. 9a-d) but did not exceed $45 \mathrm{dBZ}$ in this period, except at locations near the ground at 02:57 JST. Accordingly, the corresponding rainfall rate aloft did not exceed $30 \mathrm{~mm} \mathrm{~h}^{-1}$. In contrast, a high-reflectivity region $(>45 \mathrm{dBZ})$ was formed at 02:49 JST associated with cell $B$ at an altitude around $3 \mathrm{~km}$ (Fig. 9f). Accordingly, a few heavy rainfall regions $\left(>60 \mathrm{~mm} \mathrm{~h}^{-1}\right)$ were formed aloft at 02:53 JST (Fig. 9g), $8 \mathrm{~min}$ prior to the onset of heavy rainfall on the ground. The high-reflectivity region aloft descended over time, expanded in size and reached the lowest altitude of the observation (Fig. $9 \mathrm{~g}$ and h). The heavy rainfall region $\left(>60 \mathrm{~mm} \mathrm{~h}^{-1}\right)$ was located at an altitude of $1-2 \mathrm{~km}$ at 02:57 JST (Fig. 9h) at a distance of $35 \mathrm{~km}$ and reached the lowest altitude at 03:01 JST (not shown), which agrees with the onset time of the heavy local rainfall observed on the ground (Fig. 8b).

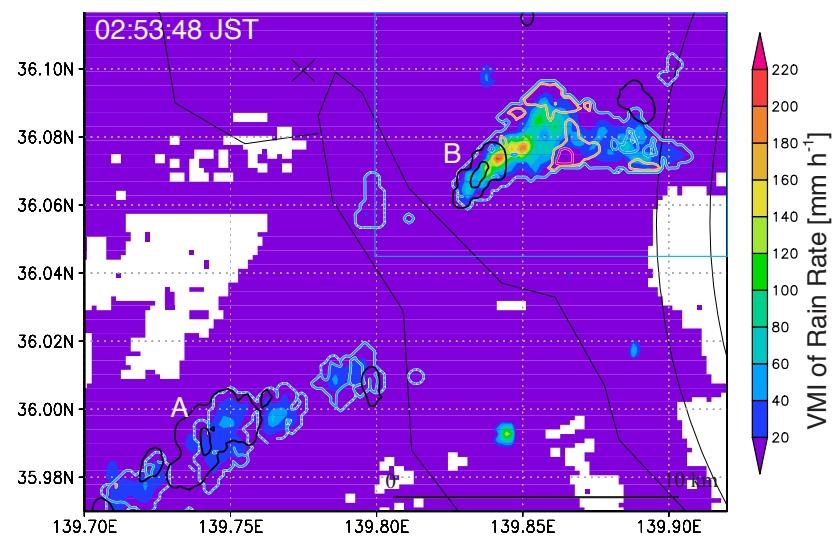

Fig. 11. The horizontal distribution of $\operatorname{VMI}\left(Z_{\mathrm{DR}}\right)$ and the surface rainfall rate superimposed over $\operatorname{VMI}(R)$, estimated from the MRI $\mathrm{C}$-band polarimetric radar at 02:53 JST. Thick black contours indicate surface rainfall rates of 3 and $18 \mathrm{~mm} \mathrm{~h}^{-1}$. Solid colored contours indicate $\operatorname{VMI}\left(Z_{\mathrm{DR}}\right)$ at altitudes above the freezing level from $0 \mathrm{~dB}$ with a contour interval of $3 \mathrm{~dB}$ (blue, orange, and red represent 0,3 , and $6 \mathrm{~dB}$, respectively), and dashed-blue contours depict $\operatorname{VMI}\left(Z_{\mathrm{DR}}\right)$ located at altitudes lower than the freezing level at $0 \mathrm{~dB}$. A blue rectangle indicates the analytical area in Figs. 12-14.

Another region with a relatively high rainfall rate aloft at a distance of $30 \mathrm{~km}$ at 02:57 JST (Fig. 9h) corresponds to $B_{2}$ in Fig. 8d, as shown later. These results suggest that rainfall rate aloft could be used to make a very short-term forecast of rainfall. Note that contours of the rainfall rate are not always parallel to those of reflectivity because the former depends not only on the latter but also on the differential reflectivity measurements, as in Eq. (7).

Another unique signature associated with cell $B$ is a vertical area of enhanced differential reflectivity extending above the freezing level, i.e. a high $Z_{\mathrm{DR}}$ column (Fig. 9f-h). Enhanced $Z_{\mathrm{DR}}$ values and a low $Z_{\mathrm{H}}$ imply the presence of oblate liquid drops because frozen raindrops cannot take such large $Z_{\mathrm{DR}}$ values even in the C-band (Fig. 2). Because the farther above the $0{ }^{\circ} \mathrm{C}$ level the column extends, the more vigorous the updraft is (Scharfenberg et al., 2005), this figure also shows that cell $B$ developed with a strong upward air motion, suggesting that cell $B$ is potentially hazardous, as it is likely to produce heavy rainfall. In the next section, we focus on the horizontal distributions of the heavy rainfall rate aloft and high $Z_{\mathrm{DR}}$ columns, because they are very important to detect potentially hazardous clouds.

\subsection{Vertical maximum intensity of rainfall rate and the $Z_{\mathrm{DR}}$ column}

In order to analyze the horizontal distributions of the vertical profiles of rainfall rate and $Z_{\mathrm{DR}}$, we have resampled the radar volume scan data from spherical coordinates to Cartesian grid data using a method proposed by Cressman (1959). The vertical profiles were then used to obtain the vertical 


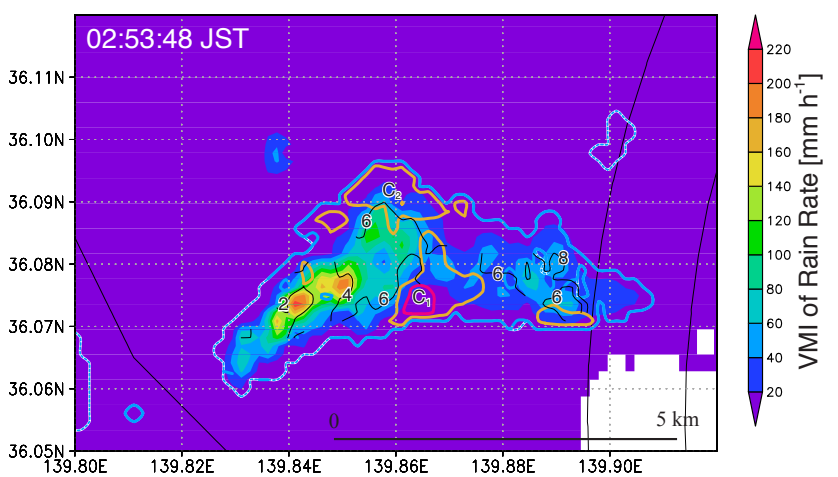

Fig. 12. The horizontal distribution of $\operatorname{VMI}\left(Z_{\mathrm{DR}}\right)$ and the expected arrival time of the maximum rainfall on the ground superimposed over $\operatorname{VMI}(R)$ estimated from the MRI C-band polarimetric radar at $02: 53 \mathrm{JST}$. Solid colored contours indicate $\operatorname{VMI}\left(Z_{\mathrm{DR}}\right)$ at altitudes above the freezing level from $0 \mathrm{~dB}$ with a contour interval of $3 \mathrm{~dB}$, and dashed-blue contours depict $\operatorname{VMI}\left(Z_{\mathrm{DR}}\right)$ located at altitudes lower than the freezing level at $0 \mathrm{~dB}$. Black contours with numbers indicate the arrival time of the maximum rainfall in minutes. $C_{1}$ and $C_{2}$ indicate the locations of high $Z_{\mathrm{DR}}$ columns.

maximum intensities of rainfall rate and $Z_{\mathrm{DR}}$. The vertical maximum intensity of the rainfall rate, $\operatorname{VMI}(R)$, is defined as

$\operatorname{VMI}(R)=\max _{z_{1} \leq z \leq z_{2}}(R(z))$,

where $z_{1}$ and $z_{2}$ are the lowest and highest altitudes for the analyses. The corresponding altitude, $z\left(R_{\max }\right)$, is defined as

$z\left(R_{\max }\right)=\underset{z_{1} \leq z \leq z_{2}}{\arg \max }(R(z))$.

The horizontal distribution of $\operatorname{VMI}(R)$ is shown in Fig. 10, along with $\operatorname{VMI}\left(Z_{\mathrm{DR}}\right)$, and the surface rainfall rate at 02:49 JST when the $Z_{\mathrm{DR}}$ column was clearly analyzed in the distance-height cross section (Fig. 9f). In the figure, the $\operatorname{VMI}\left(Z_{\mathrm{DR}}\right)$ in the area of $\operatorname{VMI}(R)>12 \mathrm{~mm} \mathrm{~h}^{-1}$ was plotted to reduce the effect of noise. The solid-colored contours depict the $\operatorname{VMI}\left(Z_{\mathrm{DR}}\right)$ at an altitude greater than or equal to $4.5 \mathrm{~km}$ a.g.l. (i.e. $z_{1}=4.5 \mathrm{~km}$ : about $200 \mathrm{~m}$ higher than the freezing level) to separate the $Z_{\mathrm{DR}}$ column from the bright band. In contrast, the dashed-blue contours depict the $\operatorname{VMI}\left(Z_{\mathrm{DR}}\right)$ of $0 \mathrm{~dB}$ located below the freezing level $\left(z\left(Z_{\mathrm{DR}_{\max }}\right)<4.3 \mathrm{~km}, z_{1}=z\left(R_{\max }\right)\right)$, and only the rainfall rate below the bright band $\left(z_{2}=4.1 \mathrm{~km}\right)$ is considered for the $\operatorname{VMI}(R)$. Note that the rainfall rate for the VMI in the present study is derived from rain-only reflectivity and $Z_{\mathrm{DR}}$, as in Eq. (7), i.e. $\operatorname{VMI}\left(R\left(Z^{\text {rain }}, Z_{\mathrm{DR}}\right)\right)$ as opposed to $\operatorname{VMI}\left(R\left(Z^{\mathrm{obs}}\right)\right)$ proposed by Vulpiani et al. (2012).

At that time, the difference in the rainfall rate on the ground between cells $A$ and $B$ was small; both were less than $5 \mathrm{~mm} \mathrm{~h}^{-1}$. However, the $\operatorname{VMI}(R)$ shows that cell $B$ was associated with a heavy rainfall region $\left(>60 \mathrm{~mm} \mathrm{~h}^{-1}\right)$ in a small area aloft. Moreover, two enhanced $Z_{\mathrm{DR}}$ regions associated

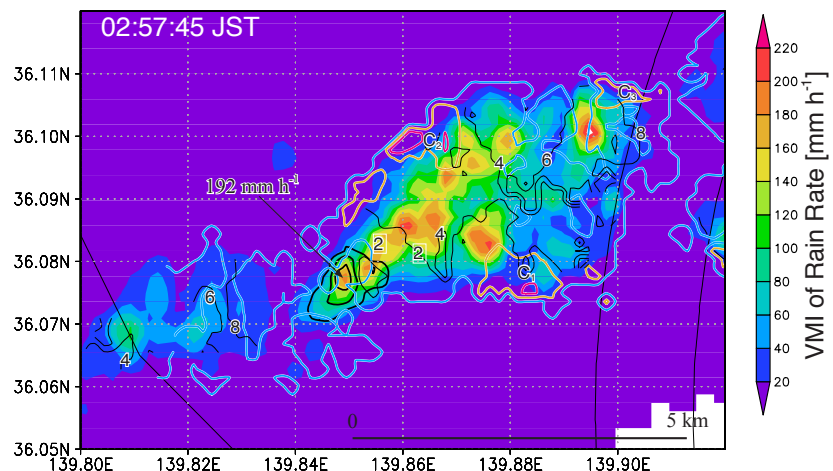

Fig. 13. The horizontal distribution of $\operatorname{VMI}\left(Z_{\mathrm{DR}}\right)$ and the expected arrival time of the maximum rainfall on the ground superimposed over $\operatorname{VMI}(R)$ estimated from the MRI C-band polarimetric radar at 02:57 JST. Solid colored contours indicate $\operatorname{VMI}\left(Z_{\mathrm{DR}}\right)$ at altitudes above the freezing level from $0 \mathrm{~dB}$ with a contour interval of $3 \mathrm{~dB}$. Thin black contours with numbers show the expected arrival time of the maximum intensity rainfall in minutes; thick black contours indicate the estimated surface rainfall rate from $50 \mathrm{~mm} \mathrm{~h}^{-1}$ with a contour interval of $50 \mathrm{~mm} \mathrm{~h}^{-1}$. The arrow indicates the location of the maximum surface rainfall rate, and $C_{1}-C_{3}$ depict the locations of high $Z_{\mathrm{DR}}$ columns.

with the $Z_{\mathrm{DR}}$ columns (Fig. 9f) were clearly analyzed at an altitude higher than the freezing level above the heavy rainfall region, suggesting that cell $B$ was associated with strong updrafts that could rapidly develop convective cloud and intensify the rainfall rate aloft over time. In contrast, cell $A$ was not associated with enhanced $Z_{\mathrm{DR}}$ regions at high altitude, which is consistent with Fig. $9 b$.

Subsequent radar observations captured the formation and evolution of localized heavy rainfall events. Four minutes later (Fig. 11), the surface rainfall rates associated with cells $A$ and $B$ estimated from the radar were still small in both size and intensity $\left(<20 \mathrm{~mm} \mathrm{~h}^{-1}\right)$. However, there are quite distinct differences aloft. The $\operatorname{VMI}(R)$ clearly shows that cell $B$ is potentially more hazardous because a rainfall rate greater than $160 \mathrm{~mm} \mathrm{~h}^{-1}$ is estimated over a large area for cell $B$, but a rainfall rate of less than $60 \mathrm{~mm} \mathrm{~h}^{-1}$ is estimated for cell $A$ over a small regions. This suggests that the $\operatorname{VMI}(R)$ associated with cell $B$ increased more than the $\operatorname{VMI}(R)$ for cell $A$ over a short time, as expected. The two large regions of enhanced $Z_{\mathrm{DR}}$ associated with cell $B$ at an altitude higher than the freezing level were analyzed again near the center of the high rainfall rate region aloft, which is surrounded by contours of the $\operatorname{VMI}\left(Z_{\mathrm{DR}}\right)$ at $0 \mathrm{~dB}$. Note that cell $A$ was not associated with either enhanced $Z_{\mathrm{DR}}$ or high $\operatorname{VMI}(R)$ regions, suggesting that cell $A$ was less hazardous at this stage and unlikely to produce heavy rain. This result is consistent with the evolution of the rainfall rate near the ground (Fig. 8). The remainder of our analysis focuses on cell $B$ because it was more hazardous. 


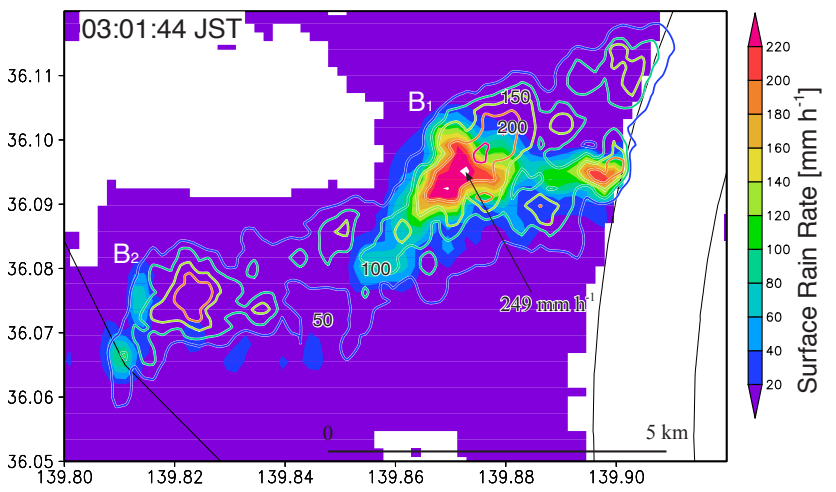

Fig. 14. The horizontal distribution of $\operatorname{VMI}(R)$ superimposed over the rainfall rate on the ground estimated from the MRI C-band polarimetric radar at 03:01 JST. The arrow indicates the location of the estimated maximum rainfall rate on the ground, and the colored contours indicate $\operatorname{VMI}(R)$ from $50 \mathrm{~mm} \mathrm{~h}^{-1}$ with a contour interval of $50 \mathrm{~mm} \mathrm{~h}^{-1}$.

The maximum rainfall associated with cell $B$ occurred at the surface when raindrops at the altitude of the $\operatorname{VMI}(R)$ reached the ground. The arrival time of the maximum rainfall could be estimated from the terminal velocity derived from rain-only reflectivity (Joss and Waldvogel, 1970) and the altitude of the $\operatorname{VMI}(R)$, i.e. $z\left(R_{\max }\right)$. The expected lead time of heavy rain and the $\operatorname{VMI}\left(Z_{\mathrm{DR}}\right)$ superimposed over the $\operatorname{VMI}(R)$ at 02:53 JST are shown in Fig. 12. The effect of air density on the terminal velocity of raindrops (Foote and du Toit, 1969) was not considered when determining the lead time because no sounding data were available at the time.

Figure 12 shows that very heavy rainfall (more than $150 \mathrm{~mm} \mathrm{~h}^{-1}$ ) was expected on the ground within $4 \mathrm{~min}$ in very small areas in the southwest part of a high rainfall rate region aloft associated with cell $B$. The peak $\operatorname{VMI}(R)$ value between 2 and $6 \mathrm{~min}$ was as high as $190 \mathrm{~mm} \mathrm{~h}^{-1}$. Moreover, two enhanced $Z_{\mathrm{DR}}(>3 \mathrm{~dB})$ regions corresponding to the high- $Z_{\mathrm{DR}}$ columns were apparent to the east $\left(C_{1}\right)$ and northeast $\left(C_{2}\right)$, suggesting that cell $B$ was still accompanied by strong updrafts and the intense rainfall region was expanding aloft northeastwardly.

Subsequent observations indicate that the intensified $\operatorname{VMI}(R)$ region expanded northeastwardly for $4 \mathrm{~min}$, and very heavy rainfall on the ground over a very limited area was observed $\left(\sim 200 \mathrm{~m}\right.$ in width for $\left.R>100 \mathrm{~mm} \mathrm{~h}^{-1}\right)$ at 02:57 JST, as expected (Fig. 13), and the rainfall rate on the ground $\left(192 \mathrm{~mm} \mathrm{~h}^{-1}\right)$ was very close to expected $\left(190 \mathrm{~mm} \mathrm{~h}^{-1}\right)$. Because some patches of heavy $\operatorname{VMI}(R)$ (more than $150 \mathrm{~mm} \mathrm{~h}^{-1}$ ) formed northeast of the heavy rainfall aloft, a northeastward expansion of the heavy rainfall region on the ground should be expected. The peak value of $\operatorname{VMI}(R)$ between 2 and $6 \mathrm{~min}$ was $214 \mathrm{~mm} \mathrm{~h}^{-1}$ at the time. The high- $Z_{\mathrm{DR}}$ column to the north, $C_{2}$, decreased in size, but $C_{1}$ to the south was still distinct, and another high- $Z_{\mathrm{DR}}$ column, $C_{3}$, was formed to the northeast. This suggests that cell $B$ was still active and expanding northeastwardly, which is consistent with subsequent observations near the ground (Fig. 8).

Note that another relatively intense $\operatorname{VMI}(R)$ region $\left(>80 \mathrm{~mm} \mathrm{~h}^{-1}\right)$ was observed to the west of the heavy surface rainfall region. This region corresponds to another convective cell $B_{2}$ (Fig. 8d) at its developmental stage. Although a high$Z_{\mathrm{DR}}$ column is not apparent in the figure, $B_{2}$ was expected to develop to some extent because an enhanced vertical $Z_{\mathrm{DR}}$ region is present just below the freezing level (Fig. $9 g$ and $h$ ).

Isochrones of the expected lead time of heavy rainfall and the $\operatorname{VMI}(R)$ indicate that heavy rainfall $\left(>100 \mathrm{~mm} \mathrm{~h}^{-1}\right)$ associated with cell $B$ will occur on the ground over a large area within $4 \mathrm{~min}$. This estimation is confirmed by observations near the ground (Fig. 14), although the peak rainfall rate on the ground $\left(249 \mathrm{~mm} \mathrm{~h}^{-1}\right)$ was slightly greater than expected $\left(214 \mathrm{~mm} \mathrm{~h}^{-1}\right)$. The surface rainfall rate shown in this figure is the same as that in Fig. 8b. A rainfall rate greater than $100 \mathrm{~mm} \mathrm{~h}^{-1}$ occurs over a large area ( $>3 \mathrm{~km}$ in width), as expected. This was the onset of the localized heavy rainfall. A large intensified $\operatorname{VMI}(R)$ region expanding northeastwardly aloft is shown in this figure, suggesting that heavy rainfall on the ground will occur over a larger area within a short time. In addition, the surface rainfall rate associated with $B_{2}$ was not as strong $\left(\sim 60 \mathrm{~mm} \mathrm{~h}^{-1}\right)$ at that time, but the $\operatorname{VMI}(R)$ suggests that heavy rainfall $\left(\sim 250 \mathrm{~mm} \mathrm{~h}^{-1}\right)$ was occurring in this region, which is also confirmed by subsequent observations near the ground (Fig. 8d).

\section{Concluding remarks}

In this study we have demonstrated a very short-term rainfall forecast method to detect potentially hazardous convective clouds that produce localized heavy rainfall based on actual volumetric C-band polarimetric radar data. The effects of hail in radar observation volumes have caused large errors in short-term rainfall forecasts that rely only on radar reflectivity, although hail constitute an important part to generate high rainfall rates. However, the method presented in this study is immune to the high reflectivity associated with hail because it includes a rainfall estimation algorithm that removes the effect of ice particles based on polarimetric measurements. In the retrieval of the rainfall rate, an attenuation correction is also included using polarimetric measurements.

To evaluate the algorithm, we compared the rainfall rate estimated from polarimetric radar measurements at the lowest elevation angle with results obtained from two optical disdrometers on the ground, and we demonstrated that the rainfall rate estimated from polarimetric data agreed well with the disdrometer results and was much more reliable than estimations derived from reflectivity alone. The high stability of the solid-state transmitters of the radar also contributed to this observation. Additionally, this stability enables the radar with high integrity to undertake $4 \mathrm{~min}$ volumetric 
scans, which is a sufficiently high time resolution to make polarimetric measurements for convective clouds at the development stage.

We analyzed two small cumulus cells that were located close to each other, one of which developed and later produced heavy rainfall, whereas the other did not develop significantly. The distance-height cross section of the rainfall rate along the advection direction of the cells revealed the formation of a heavy rainfall region aloft, which descended over time and produced heavy rainfall. Moreover, a high vertical maximum intensity of rainfall, $\operatorname{VMI}(R)$, was observed aloft about $8 \mathrm{~min}$ prior to the onset of the heavy rainfall on the ground. The arrival time of the maximum rainfall could be estimated from polarimetric measurements, which agreed fairly well with observations. The cumulus cell that did not produce heavy rainfall did not show these characteristics. These results suggest that the $\operatorname{VMI}(R)$ estimated from polarimetric measurements can be used as an indicator to identify potentially hazardous clouds.

We also demonstrated that polarimetric measurements, particularly a high- $Z_{\mathrm{DR}}$ column, can be used to identify hazardous cloud. High- $Z_{\mathrm{DR}}$ columns extending vertically beyond the freezing level were observed about $12 \mathrm{~min}$ prior to the onset of heavy rainfall in the potentially hazardous cloud. Additionally, because the intensity of updrafts increases with the vertical extension of the column above the $0^{\circ} \mathrm{C}$ level, this can be another indicator used to identify potentially hazardous clouds. The locations of the high- $Z_{\mathrm{DR}}$ column may also indicate the horizontal direction of cumulus development because the convective cell extended toward the region where the high- $Z_{\mathrm{DR}}$ column was located in this study, although the precise placement of high- $Z_{\mathrm{DR}}$ columns relative to the updraft differs from storm to storm (Scharfenberg et al., 2005). The inclusion of Doppler data might provide additional information to estimate the updraft and development direction, which is the subject of future work.

It should be noted that $\operatorname{VMI}(R)$ is not conserved with time but changes because of the microphysical processes of raindrops, including condensation, coalescence, evaporation, and breakup, in addition to horizontal advection. Thus, the $\operatorname{VMI}(R)$ does not always agree well with the maximum rainfall rate observed on the ground. However, along with high$Z_{\mathrm{DR}}$ columns, it can be used for identifying hazardous clouds and thereby allowing ample time for evacuation and damage mitigation, provided that this information can be conveyed to the appropriate people in time. With the advent of information technology, some early warnings have already been issued immediately after alerts were given by short-term information transfer systems, including emails to mobile phones, and lives have been saved by providing critical seconds to make preparations for earthquakes in Japan (JMA, 2007).

In summary, we confirm that the use of polarimetric radar that provides reliable polarimetric data with high spatial and time resolution is invaluable for disaster reduction. Clearly, the detailed evolution of the $\operatorname{VMI}(R)$ would remain unseen if the time resolution of the radar were coarse. In addition, the clear identification of a high- $Z_{\mathrm{DR}}$ column and its evolution would not have been possible without the dual-polarized capability of the radar. It is very encouraging that the $\operatorname{VMI}(R)$ and $Z_{\mathrm{DR}}$ columns associated with strong updrafts can serve as predictors of localized heavy rainfall, and both appear to be useful for disaster prevention in this case study.

\section{Appendix A}

\section{Evaluation of the rainfall rate measured with Parsivel disdrometer}

Here, by re-calculating preset diameters provided by a Parsivel, we show that the error in measuring the rainfall rate with Parsivel can be less than $1 \mathrm{~mm} \mathrm{~h}^{-1}$ even for a rainfall rate in excess of $30 \mathrm{~mm} \mathrm{~h}^{-1}$.

The Parsivel is a laser-optical disdrometer, initially manufactured by PM Tech (Pfinztal, Germany) and OTT (Messtechnik, Germany) after 2004, that can measure the size and fall speed of hydrometeors. The Parsivel disdrometer can measure droplet sizes from $0.25 \mathrm{~mm}$ to about $25 \mathrm{~mm}$, with 32 classes of varying diameter intervals. The velocity categories range from $0 \mathrm{~m} \mathrm{~s}^{-1}$ to $22.4 \mathrm{~m} \mathrm{~s}^{-1}$, with 32 classes of varying intervals. Details of the instrument and the measurement technique used to determine the size and velocity of hydrometeors can be found in the literature (e.g., Battaglia et al., 2010; Löffler-Mang and Joss, 2000; Tapiador et al., 2010). We received an old-type Parsivel disdrometer from PM Tech via Scintec in 2003. Two newer Parsivel disdrometers were installed from OTT in 2009. Only the old type has a power supply box on the support pillar. Three Parsivel disdrometers were located at the MRI field site, together with a weighing $\left(\right.$ Pluvio $^{2}$ ) precipitation gauge (Nemeth, 2008) and an operational tipping-bucket rain gauge to validate the reliability of the Parsivel data before comparisons with polarimetric radar estimates. The validation was performed from 14 July to 11 August 2009. Five convective rain events with a total rainfall of $75 \mathrm{~mm}$ were observed in the test period. The data set for the validation consisted of $22781 \mathrm{~min}$ data samples. The Pluvio data were used as a reference because the uncertainty of this type of gauge in terms of relative errors is reported to be less than that for tipping-bucket rain gauges (Lanza et al., 2006). The total rainfall amount measured with the Pluvio agreed to within $1 \mathrm{~mm}$ with that from the tipping-bucket rain gauge for all rain events in the test period (Yamauchi et al., 2009).

The measurements from the Parsivel disdrometer included the rainfall rate derived by an onboard application (ASDO), but here, we calculated the rainfall rate from a 32 by 32 matrix with size versus velocity elements measured with the 

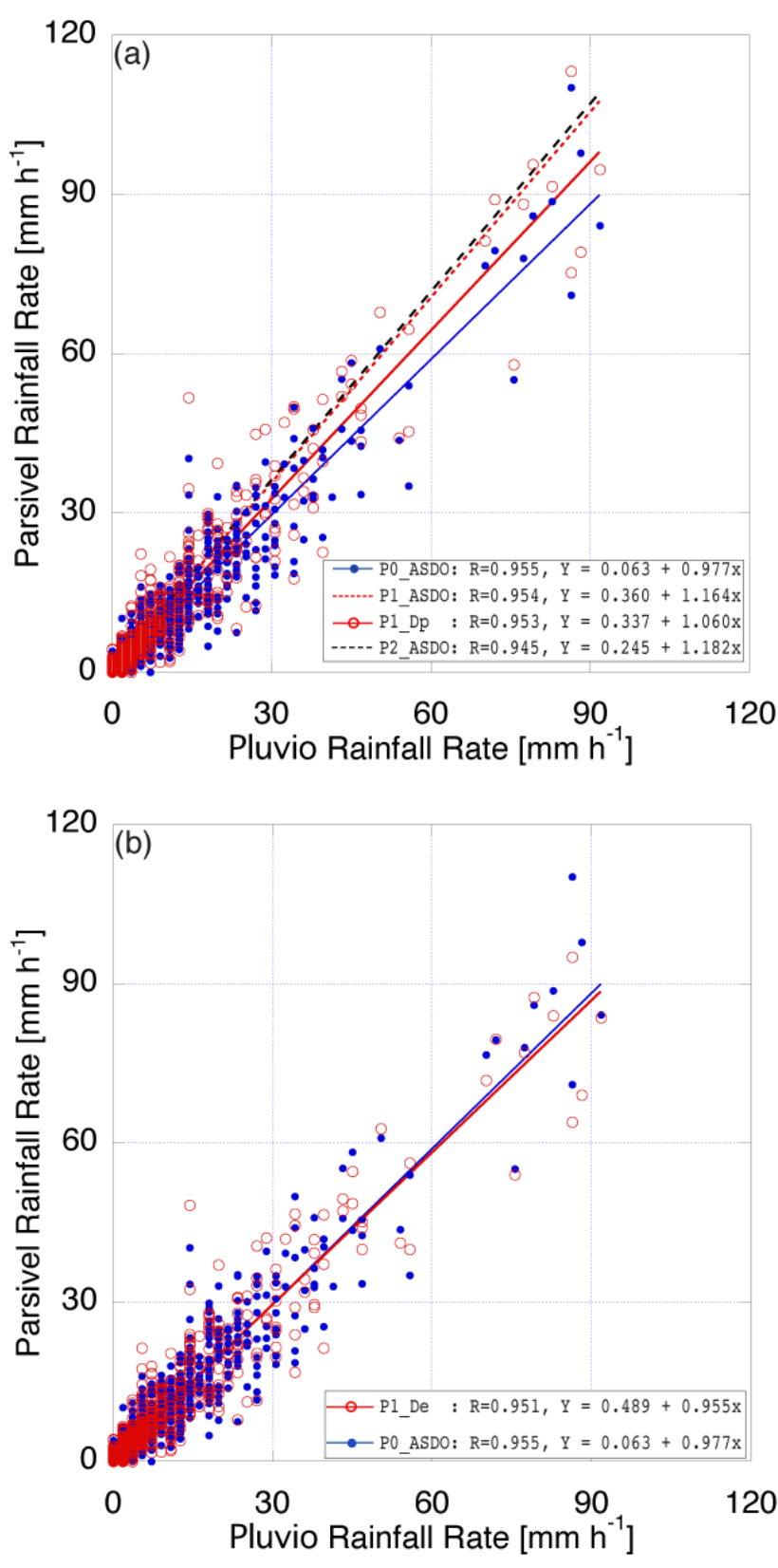

Fig. A1. Scatter plots of the rainfall rate for the Parsivel $\left(P_{0}\right.$ and $\left.P_{1}\right)$ vs. the Pluvio measurements. Rainfall rates derived from the DSD measured by $P_{1}$ are plotted as open circles using the preset diameters $\left(D_{p}\right)$ in (a) and the re-calculated diameters $\left(D_{\mathrm{e}}\right)$ in $(\mathbf{b})$, and rainfall data estimated by the on-board application software (ASDO) with $P_{0}$ are plotted as closed circles in both panels. The data were averaged over $1 \mathrm{~min}$. The lines represent linear regressions for each set of data as shown in the legends on the bottom with the correlation coefficients, $R$. The linear regressions for the data estimated by ASDO on $P_{1}$ and $P_{2}$ are also plotted with dashed lines for reference in (a).
Parsivel. The rainfall rate was calculated as follows:

$R=6 \times 10^{-4} \pi \sum_{p=1}^{32} \frac{C_{p} D_{p}^{3}}{\operatorname{Area} \cdot \Delta t}$,

where $R$ is the rainfall rate $\left(\mathrm{mm} \mathrm{h}^{-1}\right), D_{p}$ is the mid-size of the $p$ th channel (mm), $C_{p}$ is the number of drops of size $p$, Area is the measuring area $\left(=0.027 \times 0.18 \mathrm{~m}^{2}\right)$, and $\Delta t$ is the sampling time (s).

Thurai et al. (2011) reported that the rainfall rate based on the DSD calculated from a Parsivel tended to be overestimated when the rainfall rate was high (particularly above $30 \mathrm{~mm} \mathrm{~h}^{-1}$ ). This tendency of the Parsivel measurement makes it unsuitable for evaluating the reliability of the rainfall estimation algorithm from polarimetric radar measurements in heavy rainfall. We considered that this characteristic of the Parsivel data likely results from the fact that the preset $D_{p}$ value provided by the Parsivel is not an equivalent volumetric diameter but represents the measured physical maximum horizontal diameter of raindrops, as the discrepancy between the two diameters increases with size and/or rainfall intensity. This is consistent with the characteristics of the Parsivel data, although $D_{p}$ is defined as an equivalent volumetric diameter in appendix B of the Parsivel operating instructions. Physical maximum diameter is useful for studies of snow (e.g., Battaglia et al., 2010), but it needs to be transformed to equivalent volumetric diameter to calculate the rainfall rate. To confirm this assumption, we calculated the equivalent volumetric diameter $\left(D_{\mathrm{e}}\right)$ from $D_{p}$ by use of the axis ratio proposed by Beard and Chuang (1987) and recalculated the rainfall rate from the DSD using Eq. (A1) with $D_{\mathrm{e}}$ to compare with the Pluvio measurement. As a result of this modification, for instance, the 12th diameter classification reduced from 1.625 to $1.599 \mathrm{~mm}$, and the corresponding spread of classes decreased from 0.250 to $0.237 \mathrm{~mm}$, respectively.

Scatter diagrams comparing the Pluvio rainfall rate and those from the Parsivel are shown in Fig. A1. The statistics for the 1 min mean sample rainfall rate shown in Fig. A1 are given in Table A1, along with the corresponding statistics for the data with classified rainfall rates. Closed and open circles indicate data from the old $\left(P_{0}\right)$ and new $\left(P_{1}\right)$ Parsivel disdrometers, respectively. The $P_{0}$ data were processed with ASDO, but the $P_{1}$ data were reprocessed with preset diameters $\left(D_{p}\right)$ and with calculated diameters $\left(D_{\mathrm{e}}\right)$ in Fig. A1a and $b$, respectively. Only the data identified as "rain" by ASDO were used. Furthermore, to eliminate spurious drops, a matrix was used that rejected drops bigger than $8 \mathrm{~mm}$ and drops falling at velocities that differed by more than $50 \%$ of the empirical fall speed (Gunn and Kinzer, 1949) based on Sánchez (2006). Rainfall rate data exceeding $0 \mathrm{~mm} \mathrm{~h}^{-1}$ from the Parsivel are plotted in the figure, although the minimum rainfall rate of the Pluvio was $1.8 \mathrm{~mm} \mathrm{~h}^{-1}$. Note that the number of observations for each instrument is the same in each panel. However, the number of observations using $P_{1}$ was smaller than the number using $P_{0}$ in each panel because 
Table A1. Statistical values for the comparison of Parsivel $\left(P_{0}, P_{1}\right.$, and $\left.P_{2}\right)$ vs. Pluvio measurements of the (top) total points, $(2$ nd row) bias, (3rd row) standard deviation, and (bottom) root mean square of the rainfall rate differences. Rainfall rate data were derived from on-board software (ASDO) and from the DSD with the preset diameters $\left(D_{\mathrm{p}}\right)$ and with the re-calculated equivalent volumetric diameters $\left(D_{\mathrm{e}}\right)$.

\begin{tabular}{|c|c|c|c|c|c|c|c|}
\hline & & $\begin{array}{r}\text { All } \\
\text { data }\end{array}$ & $\begin{array}{r}R \geq 1.8 \\
\mathrm{~mm} \mathrm{~h}^{-1}\end{array}$ & $\begin{array}{r}R \geq 10 \\
\mathrm{~mm} \mathrm{~h}^{-1}\end{array}$ & $\begin{array}{r}R \geq 20 \\
\mathrm{~mm} \mathrm{~h}^{-1}\end{array}$ & $\begin{array}{r}R \geq 25 \\
\mathrm{~mm} \mathrm{~h}^{-1}\end{array}$ & $\begin{array}{r}R \geq 30 \\
\mathrm{~mm} \mathrm{~h}^{-1}\end{array}$ \\
\hline \multirow{3}{*}{ Total points } & $P_{0}$ & 2278 & 1689 & 296 & 124 & 75 & 53 \\
\hline & $P_{1}$ & 1065 & 749 & 182 & 92 & 61 & 48 \\
\hline & $P_{2}$ & 2278 & 1689 & 296 & 124 & 75 & 53 \\
\hline \multirow{7}{*}{$\operatorname{Bias}\left(\mathrm{mm} \mathrm{h}^{-1}\right)$} & $P_{0}(\mathrm{ASDO})$ & 0.0 & -0.1 & -0.2 & -0.4 & -0.3 & 0.7 \\
\hline & $P_{1}(\mathrm{ASDO})$ & 1.5 & 2.1 & 5.2 & 6.8 & 9.0 & 10.2 \\
\hline & $P_{1}\left(D_{\mathrm{p}}\right)$ & 0.8 & 1.1 & 2.4 & 3.1 & 4.2 & 4.7 \\
\hline & $P_{1}\left(D_{\mathrm{e}}\right)$ & 0.3 & 0.3 & 0.1 & -0.6 & -0.5 & -0.6 \\
\hline & $P_{2}(\mathrm{ASDO})$ & 1.2 & 1.5 & 4.8 & 6.6 & 8.2 & 10.6 \\
\hline & $P_{2}\left(D_{\mathrm{p}}\right)$ & 0.6 & 0.7 & 2.4 & 2.8 & 3.4 & 5.0 \\
\hline & $P_{2}\left(D_{\mathrm{e}}\right)$ & 0.3 & 0.2 & 0.3 & -0.6 & -1.1 & -0.4 \\
\hline \multirow{7}{*}{ Standard deviation $\left(\mathrm{mm} \mathrm{h}^{-1}\right)$} & $P_{0}(\mathrm{ASDO})$ & 3.0 & 3.5 & 7.6 & 10.2 & 12.3 & 13.8 \\
\hline & $P_{1}(\mathrm{ASDO})$ & 5.7 & 6.7 & 12.4 & 15.4 & 17.8 & 19.2 \\
\hline & $P_{1}\left(D_{\mathrm{p}}\right)$ & 5.0 & 6.0 & 11.3 & 14.3 & 16.7 & 18.1 \\
\hline & $P_{1}\left(D_{\mathrm{e}}\right)$ & 4.4 & 5.3 & 10.0 & 12.5 & 14.7 & 15.9 \\
\hline & $P_{2}(\mathrm{ASDO})$ & 4.6 & 5.4 & 11.3 & 15.1 & 18.1 & 20.1 \\
\hline & $P_{2}\left(D_{\mathrm{p}}\right)$ & 4.1 & 4.7 & 10.3 & 14.0 & 16.9 & 19.1 \\
\hline & $P_{2}\left(D_{\mathrm{e}}\right)$ & 3.6 & 4.2 & 9.1 & 12.3 & 14.7 & 16.7 \\
\hline \multirow{7}{*}{ Rms difference $\left(\mathrm{mm} \mathrm{h}^{-1}\right)$} & $P_{0}(\mathrm{ASDO})$ & 3.0 & 3.5 & 7.6 & 10.2 & 12.3 & 13.8 \\
\hline & $P_{1}(\mathrm{ASDO})$ & 5.9 & 7.0 & 13.4 & 16.9 & 19.9 & 21.7 \\
\hline & $P_{1}\left(D_{\mathrm{p}}\right)$ & 5.1 & 6.0 & 11.5 & 14.6 & 17.2 & 18.7 \\
\hline & $P_{1}\left(D_{\mathrm{e}}\right)$ & 4.4 & 5.3 & 10.0 & 12.6 & 14.7 & 15.9 \\
\hline & $P_{2}(\mathrm{ASDO})$ & 4.8 & 5.6 & 12.3 & 16.5 & 19.8 & 22.8 \\
\hline & $P_{2}\left(D_{\mathrm{p}}\right)$ & 4.1 & 4.8 & 10.6 & 14.3 & 17.2 & 19.7 \\
\hline & $P_{2}\left(D_{\mathrm{e}}\right)$ & 3.6 & 4.2 & 9.1 & 12.3 & 14.8 & 16.7 \\
\hline
\end{tabular}

the operation of the former ceased on 23 August when it was moved to Sekiyado for comparison with the polarimetric radar. Thus, the data measured with another new Parsivel disdrometer $\left(P_{2}\right)$, whose number of observations was identical to that of $P_{0}$, were also considered in the statistics. The linear regressions of $P_{1}$ measurements processed by ASDO agreed well with $P_{2}$ measurements, as shown in Fig. A1a, suggesting that the statistical characteristics of the two Parsivel measurements were similar despite the difference in the number of observations. Other linear regressions for $P_{2}$ measurements were too close to those of $P_{1}$ to depict in the panels.

The linear regressions for $P_{1}$ from both ASDO and the DSD with $D_{p}$ (hereafter referred to as the $D_{p}$ method) indicate a tendency for the Parsivel to overestimate (Fig. A1a), as Thurai et al. (2011) also observed. However, it should be noted that the linear regression for $P_{0}$ with ASDO is almost on the $1: 1$ line, suggesting that the $P_{0}$ measurements agree well with those of the Pluvio. This result suggests that there is a difference in the system between the old and new Par- sivel disdrometers. The observation that the old Parsivel has good reliability agrees with the results of Sánchez (2006) and Tokay et al. (2013). However, the linear regression for the rainfall rate estimated from the DSD with $D_{\mathrm{e}}$ (hereafter the $D_{\mathrm{e}}$ method) derived from $P_{1}$ is also almost on the $1: 1$ line (Fig. A1b). This is reflected in the statistics for the $D_{p}$ method versus the $D_{\mathrm{e}}$ method in Table A1.

We computed several statistics to explore the relationship between the time series of 1 min-averaged measurements from the weighing precipitation gauge, Pluvio $\left(W_{i}\right)$, and the Parsivel $\left(P_{i}\right)$. The statistics are based on the difference between the two platforms, $D_{i}=P_{i}-W_{i}$. For the rainfall rate from the new Parsivel disdrometers $\left(P_{1}\right.$ and $\left.P_{2}\right)$, we used the rate determined by $\mathrm{ASDO}$, estimated from the $D_{p}$ method and the $D_{\mathrm{e}}$ method. Statistics for the rainfall rate from the old Parsivel $\left(P_{0}\right)$ were processed with ASDO calculated as a reference. The bias (systematic error) of the rainfall rate is

$\mu_{D}=\frac{1}{N} \sum_{i=1}^{N}\left(P_{i}-W_{i}\right)=\frac{1}{N} \sum_{i=1}^{N} D_{i}$, 


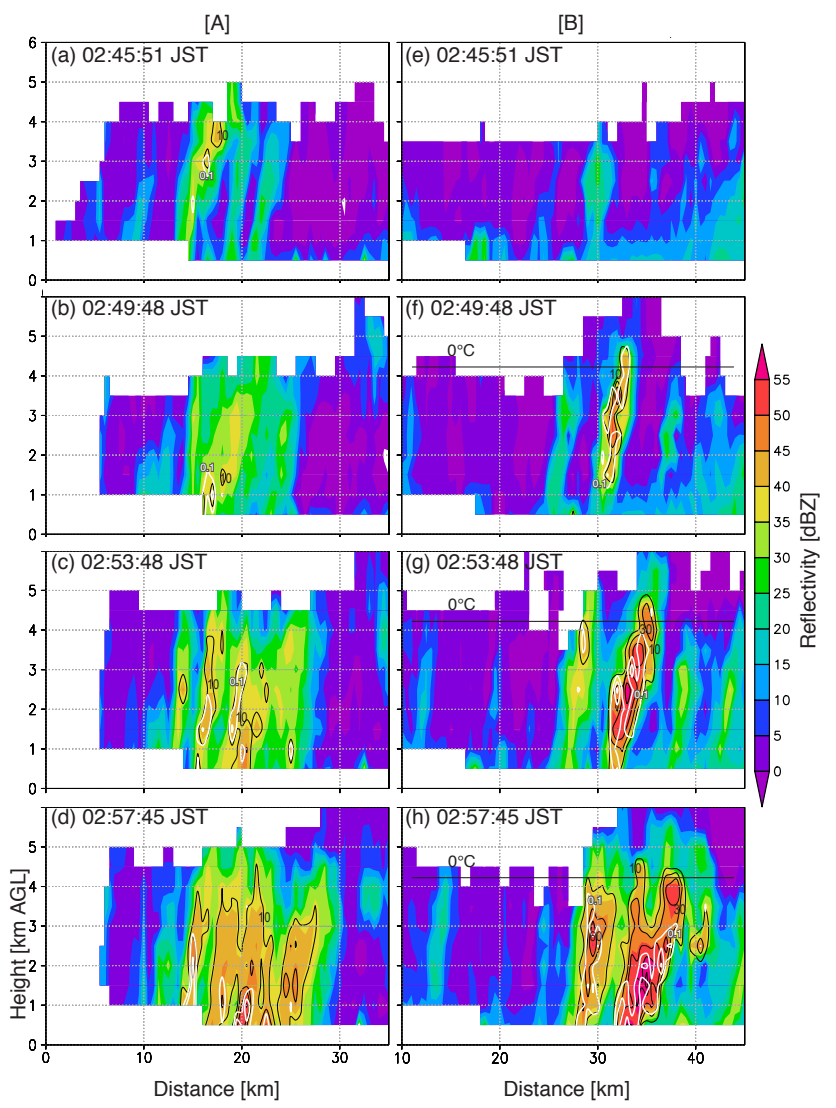

Fig. A2. Distance-height cross section of rainfall rate and ice fraction superimposed over the attenuation-corrected reflectivity of $A(\mathbf{a}-\mathbf{d})$ and $B(\mathbf{e}-\mathbf{h})$ along the analytic area in Fig. 8. Black contours indicate estimated rainfall rates from a $Z-R$ relation of 10 , $30,60,120$ and $180 \mathrm{~mm} \mathrm{~h}^{-1}$, and white contours depict ice fraction from 0.1 with a contour interval of 0.1 . The observation time is shown in the upper-left of each image.

and the standard deviation (precision) is

$\sigma_{D}=\left[\frac{1}{N} \sum_{i=1}^{N}\left(D_{i}-\mu_{D}\right)^{2}\right]^{\frac{1}{2}}$,

where $N$ is the number of observations. We also calculated the root mean square of the rainfall rate differences as follows:

$\mathrm{rms}=\left[\frac{1}{N} \sum_{i=1}^{N} D_{i}^{2}\right]^{\frac{1}{2}}$.

The statistics for the 1 min mean sample rainfall rates are given in Table A1, along with the corresponding statistics for the data derived from the three Parsivels for different methods and thresholds. The rainfall rates measured with the Pluvio are used for the rainfall rate classifications with a threshold value. Note that the minimum detectable rainfall rate with the Pluvio was $1.8 \mathrm{~mm} \mathrm{~h}^{-1}$, but all the data identified as "rain" by ASDO were considered. However, Parsivel

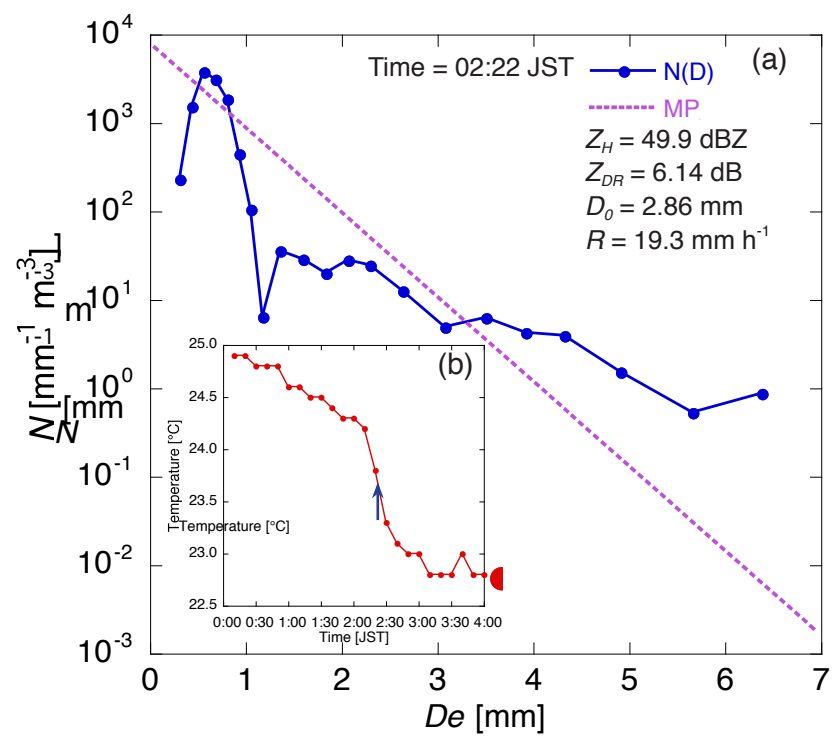

Fig. A3. Measurements at the Kumagaya station of (a) raindrop size distribution at 02:22 JST averaged over $1 \mathrm{~min}$ by a Parsivel disdrometer and (b) time series of surface temperature from 00:00 to 04:00 JST on 7 July 2010. Lines with closed circles in (a) indicate the observed drop size distribution with the corresponding $Z_{\mathrm{H}}, Z_{\mathrm{DR}}, D_{0}$, and rainfall rate on the upper right. The dashed line depicts an exponential Marshall-Palmer fit at a rainfall rate of $19.3 \mathrm{~mm} \mathrm{~h}^{-1}$. The arrow in (b) indicates the time of DSD measurement.

data that did not have corresponding Pluvio data for the same time were removed before the comparison.

The standard deviation of $P_{1}$ increased with the threshold of the rainfall rate for each method. The reason for this increase may include the decrease in sample number with the rainfall rate. The standard deviation of the rainfall rate derived from the $D_{\mathrm{e}}$ method was always lower than values derived using the other method. The reason for the standard deviations derived using the $D_{\mathrm{e}}$ method were lower than those derived using the $D_{p}$ method may include the fact that the class spread for each $D_{\mathrm{e}}$ was smaller than that for $D_{p}$. These tendencies can be seen in the root mean square of the rainfall rate derived from $P_{1}$. However, the bias has very different characteristics.

The biases of $P_{1}$, both with ASDO and the $D_{p}$ method, increased with the threshold of rainfall rate. This systematic tendency toward an increase in bias with rainfall rate was consistent with the result of Thurai et al. (2011). In contrast, the bias derived from $P_{1}$ with the $D_{\mathrm{e}}$ method did not vary much with rainfall rate. The bias was less than $1 \mathrm{~mm} \mathrm{~h}^{-1}$ even for a rainfall rate greater than $30 \mathrm{~mm} \mathrm{~h}^{-1}$. This characteristic agrees well with the bias of $P_{0}$ with ASDO, suggesting that $P_{0}$ uses the $D_{\mathrm{e}}$ method. It should be noted that the differences between $P_{1}$ and $P_{2}$ for all statistical values were less than $1.5 \mathrm{~mm} \mathrm{~h}^{-1}$ even for large statistical values. This may suggest that the $D_{\mathrm{e}}$ method is reliable for Parsivel 
disdrometers of this type. However, both the standard deviations and the root mean square of the rainfall rate differences derived by the $D_{\mathrm{e}}$ method were always larger than those for $P_{0}$ with ASDO. This is likely because ASDO with $P_{0}$ is equipped with a better quality-control matrix for the DSD. Because the $D_{\mathrm{e}}$ method is more accurate, we used it to retrieve the rainfall rates both from $P_{1}$ and $P_{2}$ in the comparisons with the polarimetic radar estimations in this study. For the comparison, $P_{2}$ was moved to Kumagaya after this validation.

\section{Appendix B}

\section{Effects of ice hydrometeors on the estimation of rainfall rate}

As the rainfall estimation algorithm used in the proposed method removes the effects of ice particles, it is insensitive to the high reflectivity associated with dry hail, which is randomly oriented and statistically isotropic. However, this algorithm would not work well for oriented ice hydrometeors, including wet/melting hail because the assumption on which the algorithm is based becomes invalid. This appendix focuses on the effects of ice particles on the estimation of rainfall rate and discusses the influence of wet/melting hydrometeors on the proposed method.

The evolution of the distance-height cross section of the attenuation-corrected reflectivity field along with the rainfall rate and ice fraction is shown in Fig. A2. This figure corresponds to Fig. 9 except that the reflectivity is due not only to rain but also to a mixture of ice hydrometeors and rain. Moreover, the rainfall rate estimation does not use $Z_{\mathrm{DR}}$ but relies only on the attenuation-corrected reflectivity using Eq. (8). This figure shows that ice hydrometeors were formed aloft and fell in cell B. In contrast, cell A did not have a clear ice particle signature, suggesting that only cell B was associated with strong upward air motions that enabled hail/graupel to grow, which is consistent with the analysis of the high $Z_{\mathrm{DR}}$ columns in Sect. 4.2.

The reflectivity in cell B in Fig. A2 was larger than that in Fig. 9 because of ice hydrometeors, which resulted in a much heavier rainfall rate, especially at $02: 57 \mathrm{JST}\left(120 \mathrm{~mm} \mathrm{~h}^{-1}\right.$ vs. $60 \mathrm{~mm} \mathrm{~h}^{-1}$, respectively). The overestimation due to ice particles is one of the causes of the large errors in the retrieval of quantitative rainfall forecasts using vertically integrated liquid water content (VIL) as mentioned in Sect. 1. This result demonstrates the advantage of the proposed method for improving very short-term precipitation forecasting. However, this method cannot remove all of the effects of ice hydrometeors.

The algorithm in the present study assumes a statistically isotopic orientation of ice particles, which is valid for pureice hail/graupel. However, this assumption is invalid for incompletely melted hydrometeors, including wet/melting hail, because they are likely to be anisotropic and oriented. Ice hydrometeors are often recognized in drop size distribution (DSD) measurements. The DSD observed at the Kumagaya station at 02:22 JST on 7 July 2010 is shown in Fig. A3a. Here, it corresponds to the period when a large discrepancy was observed between radar estimates and disdrometer measurements at the Kumagaya station (Fig. 5b). It is clear that the relatively high concentration of large drops with $D_{\mathrm{e}}>3 \mathrm{~mm}$ makes it difficult to fit the DSD with positive $\mu$-values of a gamma distribution. As the shape of the DSD tends to deviate from the gamma shape when the ice phase is involved in precipitation (Bringi and Chandrasekar, 2001), this result suggests that ice hydrometeors were included at this time, which was also supported by the corresponding temperature decrease (Fig. A3b). The ice hydrometeors were likely wet/melting hail/graupel because the falling velocities of dry hail/graupel (snow) are much faster (slower) than that of rain, and quality control used for Parsivel measurements should reject such data before the DSD calculation (see Appendix A).

These results suggest that an overestimation due to wet/melting hydrometeors may occur aloft even with the proposed algorithm, although their occurrence could be less frequent on the ground (Fig. 5). This overestimation may also explain why the vertical maximum intensity of the rainfall rate, VMI $(R)$, does not always agree well with the maximum rainfall rate observed on the ground, in addition to other factors described in Sec. 5. However, it is difficult to remove the effect of wet/melting hail/graupel even for advanced algorithms with polarimetric radars (e.g., Picca and Ryzhkov, 2011; Ryzhkov et al., 2009). Nevertheless, the proposed algorithm is much more reliable than the $R\left(Z_{H}\right)$ method (Figs. 5, 9 and A2) and can be used to identify hazardous clouds.

Acknowledgements. The authors would like to express their gratitude to V. N. Bringi of Colorado State University for many helpful discussions and comments regarding the research presented. The authors also wish to thank A. Ryzhkov of the NOAA National Severe Storms Laboratory for his valuable comments on high $Z_{\mathrm{DR}}$ columns. We also express our appreciation to A. Illingworth of the University Reading for his valuable input and guidance on the auto-calibration technique. The first author wishes to thank D. Cimini of IMAA-CNR for many helpful comments regarding the research presented. Comments from two anonymous reviewers led to several improvements in the paper. This study was partially supported by Japan Society for the Promotion of Science (JSPS) Grant-in-Aid for Scientific Research (22510200) and by the funds for integrated promotion of social system reform, research and development of the Ministry of Education, Culture, Sports, Science and Technology (MEXT) of Japan.

Edited by: F. S. Marzano 


\section{References}

Anagnostou, E. N., Anagnostou, M. N., Krajewski, W. F., Kruger, A., and Miriovsky, B. J.: High-resolution rainfall estimation from X-band polarimetric radar measurements, J. Hydrol., 5, 110-128, doi:10.1175/1525-7541(2004)005<0110:hrefxp>2.0.co;2, 2004.

Battaglia, A., Rustemeier, E., Tokay, A., Blahak, U., and Simmer, C.: PARSIVEL snow observations: A critical assessment, J. Atmos. Ocean. Tech., 27, 333-344, doi:10.1175/2009jtecha1332.1, 2010.

Beard, K. V. and Chuang, C.: A new model for the equilibrium shape of raindrops, J. Atmos. Sci., 44, 1509-1524, 1987.

Borga, M., Anagnostou, E. N., Blöschl, G., and Creutin, J.D.: Flash flood forecasting, warning and risk management: the HYDRATE project, Environ. Sci. Policy, 14, 834-844, doi:10.1016/j.envsci.2011.05.017, 2011.

Boudevillain, B. and Andrieu, H.: Assessment of vertically integrated liquid (VIL) water content radar measurement, J. Atmos. Ocean. Technol., 20, 807-819, doi:10.1175/15200426(2003)020<0807:aovilv>2.0.co;2, 2003.

Boudevillain, B., Andrieu, H., and Chaumerliac, N.: Evaluation of RadVil, a radar-based very short-term rainfall forecasting model, J. Hydrol., 7, 178-189, doi:10.1175/jhm481.1, 2006.

Brandes, E. A., Vivekanandan, J., Tuttle, J. D., and Kessinger, C. J.: A study of thunderstorm microphysics with multiparameter radar and aircraft observations, Mon. Weather Rev., 123, 3129-3143, doi:10.1175/1520-0493(1995)123<3129:asotmw>2.0.co;2, 1995.

Brandes, E. A., Zhang, G., and Vivekanandan, J.: Experiments in Rainfall Estimation with a Polarimetric Radar in a Subtropical Environment, J. Appl. Meteorol., 41, 674-685, doi:10.1175/1520-0450(2002)041<0674: eirewa>2.0.co;2, 2002.

Brandes, E. A., Zhang, G., and Vivekanandan, J.: Drop size distribution retrieval with polarimetric radar: Model and application, J. Appl. Meteorol., 43, 461-475, doi:10.1175/15200450(2004)043<0461:dsdrwp>2.0.co;2, 2004.

Brandes, E. A., Zhang, G., and Vivekanandan, J.: Corrigendum, J. Appl. Meteorol., 44, p. 186, doi:10.1175/15200450(2005)44<186:c > 2.0.co;2, 2005.

Brauer, C. C., Teuling, A. J., Overeem, A., van der Velde, Y., Hazenberg, P., Warmerdam, P. M. M., and Uijlenhoet, R.: Anatomy of extraordinary rainfall and flash flood in a Dutch lowland catchment, Hydrol. Earth Syst. Sci., 15, 1991-2005, doi:10.5194/hess15-1991-2011, 2011.

Bringi, V. N. and Chandrasekar, V.: Polarimetric Doppler Weather Radar: Principles and Applications, Cambridge University Press, 2001.

Bringi, V. N., Chandrasekar, V., Balakrishnan, N., and Zrnić, D. S.: An examination of propagation effects in rainfall on radar measurements at microwave frequencies, J. Atmos. Ocean. Tech., 7, 829-840, doi:10.1175/15200426(1990)007<0829:aeopei>2.0.co;2, 1990.

Bringi, V. N., Burrows, D. A., and Menon, S. M.: Multiparameter radar and aircraft study of raindrop spectral evolution in warm-based clouds, J. Appl. Meteorol., 30, 853880, doi:10.1175/1520-0450(1991)030<0853:mraaso > 2.0.co;2, 1991.

Byers, H. R., Roscoe, R., and Braham, J.: The Thunderstorm, report of the thunderstorm project, US Government Printing Office, Washington, D.C., 287 pp., 1949.
Chandrasekar, V. and Philips, B.: Dallas Fort Worth urban demonstration network, 7th European Conf. on Radar in Meteorology and Hydrology, Toulouse, France, 2012.

Chandrasekar, V., Bringi, V. N., Balakrishnan, N., and Zrnić, D. S.: Error structure of multiparameter radar and surface measurements of rainfall, Part III: Specific differential phase, J. Atmos. Ocean. Tech., 7, 621-629, 1990.

Cifelli, R., Chandrasekar, V., Lim, S., Kennedy, P. C., Wang, Y., and Rutledge, S. A.: A new dual-polarization radar rainfall algorithm: Application in Colorado precipitation events, J. Atmos. Ocean. Tech., 28, 352-364, doi:10.1175/2010jtecha1488.1, 2011.

Conway, J. W. and Zrnić, D. S.: A study of embryo production and hail growth using dual-doppler and multiparameter radars, Mon. Weather Rev., 121, 2511-2528, doi:10.1175/15200493(1993)121<2511:asoepa>2.0.co;2, 1993.

Cressman, G. P.: An operational objective analysis system, Mon. Weather Rev., 87, 367-374, 1959.

Foote, G. B. and du Toit, P. S.: Terminal velocity of raindrops aloft, J. Appl. Meteorol., 8, 249-253, 1969.

Glickman, T. S.: Glossary of Meteorology, 2nd Edn., Amer. Meteor. Soc., Boston, Massachusetts, USA, 855 pp., 2000.

Goddard, J. W. F., Tan, J., and Thurai, M.: Technique for calibration of meteorological radars using differential phase, Electron. Lett., 30, 166-167, 1994.

Golestani, Y., Chandrasekar, V., and Bringi, V. N.: Intercomparison of multiparameter radar measurements, Preprints of 24th Conf. on radar meteorology, Tallahassee, Florida, 1989.

Gorgucci, E., Scarchilli, G., and Chandrasekar, V.: A robust estimator of rainfall rate using differential reflectivity, J. Atmos. Ocean. Tech., 11, 586-592, doi:10.1175/15200426(1994)011<0586:areorr>2.0.co;2, 1994.

Gourley, J. J., Tabary, P., and Parent du Chatelet, J.: Data quality of the Meteo-France C-band polarimetric radar, J. Atmos. Ocean. Tech., 23, 1340-1356, doi:10.1175/jtech1912.1, 2006.

Gourley, J. J., Illingworth, A. J., and Tabary, P.: Absolute calibration of radar reflectivity using redundancy of the polarization observations and implied constraints on drop shapes, J. Atmos. Ocean. Tech., 26, 689-703, 10.1175/2008jtecha1152.1, 2009.

Greene, D. R. and Clark, R. A.: Vertically integrated liquid water - A new analysis tool, Mon. Weather Rev., 100, 548-552, doi:10.1175/1520-0493(1972)100<0548:vilwna>2.3.co;2, 1972.

Gunn, R. and Kinzer, G. D.: The terminal velocity of fall for water drops in stagnant air, J. Meteorol., 6, 243-248, 1949.

Hitschfeld, W. and Bordan, J.: Errors inherent in the radar measurement of rainfall at attenuating wavelengths, J. Meteorol., 11, 5867, doi:10.1175/1520-0469(1954)011<0058:eiitrm>2.0.co;2, 1954.

Hubbert, J. and Bringi, V. N.: An iterative filtering technique for the analysis of copolar differential phase and dual-frequency radar measurements, J. Atmos. Ocean. Tech., 12, 643-648, doi:10.1175/1520-0426(1995)012<0643:aiftft>2.0.co;2, 1995.

Hubbert, J., Bringi, V. N., Carey, L. D., and Bolen, S.: CSUCHILL polarimetric radar measurements from a severe hail storm in eastern Colorado, J. Appl. Meteorol., 37, 749-775, doi:10.1175/1520-0450(1998)037<0749:ccprmf>2.0.co;2, 1998.

Illingworth, A. J.: Improved precipitation rates and data quality by using polarimetric measurements, in: Weather radar: Principles and advanced applications, edited by: Meischner, P., SpringerVerlag, Berlin, 337 pp., 2004. 
Illingworth, A. J. and Blackman, T. M.: The need to represent raindrop size spectra as normalized gamma distributions for the interpretation of polarization radar observations, J. Appl. Meteorol., 41, 286-297, doi:10.1175/15200450(2002)041<0286:tntrrs>2.0.co;2, 2002.

Illingworth, A. J. and Thompson, R. J.: The estimation of moderate rain rates with operational polarisation radar, 32nd Conf. on Radar Meteorology, Albuquerque, 2005.

Jameson, A. R.: The effect of temperature on attenuation-correction schemes in rain using polarization propagation differential phase shift, J. Appl. Meteorol., 31, 1106-1118, doi:10.1175/15200450(1992)031<1106:teotoa>2.0.co;2, 1992.

JMA: Japan Meteorologocal Agency, Earthquake Early Warnings: http://www.jma.go.jp/jma/en/Activities/eew.html (last access: 15 March 2013), 2007.

Johnson, J. T., MacKeen, P. L., Witt, A., Mitchell, E. D. W., Stumpf, G. J., Eilts, M. D., and Thomas, K. W.: The storm cell identification and tracking algorithm: An enhanced WSR-88D algorithm, Weather Forecast., 13, 263-276, doi:10.1175/15200434(1998)013<0263:tsciat>2.0.co;2, 1998.

Joss, J. and Waldvogel, D.: Raindrop size distributions and Doppler velocities, 14th Conf. on Radar Meteorology, Tucson, AZ, 153156,1970

Kawabata, T., Kuroda, T., Seko, H., and Saito, K.: A cloudresolving 4DVAR assimilation experiment for a local heavy rainfall event in the Tokyo metropolitan area, Mon. Weather Rev., 139, 1911-1931, doi:10.1175/2011mwr3428.1, 2011.

Knight, C. A.: Very early formation of big, liquid drops revealed by $Z_{\mathrm{DR}}$ in continental cumulus, J. Atmos. Sci., 63, 1939-1953, doi:10.1175/jas3721.1, 2006.

Kobayashi, T. and Adachi, A.: Measurements of raindrop breakup by using UHF wind profilers, Geophys. Res. Lett., 28, 40714047, 2001.

Kumjian, M. R., Ryzhkov, A. V., Melnikov, V. M., and Schuur, T. J.: Rapid-scan super-resolution observations of a cyclic supercell with a dual-polarization WSR-88D, Mon. Weather Rev., 138, 3762-3786, doi:10.1175/2010mwr3322.1, 2010.

Lakshmanan, V., Smith, T., Hondl, K., Stumpf, G. J., and Witt, A.: A real-time, three-dimensional, rapidly updating, heterogeneous radar merger technique for reflectivity, velocity, and derived products, Weather Forecast., 21, 802-823, doi:10.1175/waf942.1, 2006.

Lanza, L., Leroy, M., van der Meulen, J., and Ondras, M.: The WMO laboratory intercomparison of rainfall intensity gauges, Instruments and observing methods, WMO, Geneva, 139 pp., 2006

Li, L., Schmid, W., and Joss, J.: Nowcasting of motion and growth of precipitation with radar over a complex orography, J. Appl. Meteorol., 34, 1286-1300, doi:10.1175/15200450(1995)034<1286:nomago>2.0.co;2, 1995.

Liguori, S. and Rico-Ramirez, M. A.: Quantitative assessment of short-term rainfall forecasts from radar nowcasts and MM5 forecasts, Hydrol. Process., 26, 3842-3857, doi:10.1002/hyp.8415, 2012.

Löffler-Mang, M., and Joss, J.: An optical disdrometer for measuring size and velocity of hydrometeors, J. Atmos. Ocean. Tech., 17, 130-139, doi:10.1175/15200426(2000)017<0130:aodfms>2.0.co;2, 2000.
Loney, M. L., Zrnić, D. S., Straka, J. M., and Ryzhkov, A. V.: Enhanced polarimetric radar signatures above the melting level in a supercell storm, J. Appl. Meteorol., 41, 1179-1194, doi:10.1175/1520-0450(2002)041<1179:eprsat>2.0.co;2, 2002.

Maki, M., Misumi, R., Suzuki, S., Kobayashi, T., Adachi, A., Nakamura, I., and TOMAX members,: Tokyo metropolitan area convection study for extreme weather resilient cities (TOMACS), 7th European Conf. on Radar in Meteorology and Hydrology, Toulouse, France, 2012.

Mishchenko, M. I. and Travis, L. D.: T-matrix computations of light scattering by large spheroidal particles, Opt. Commun., 109, 1621,1994

Nemeth, K.: OTT Pluvio ${ }^{2}$ : Weighing precipitation gauge and advances in precipitation measurement technology, TECO-2008 WMO Technical Conference on Meteorological and Environmental Instruments and Methods of Observation (TECO-2008), Russian Federation, St. Petersburg, 2008.

Picca, J. and Ryzhkov, A.: A dual-wavelength polarimetric analysis of the 16 May 2010 Oklahoma city extreme hailstorm, Mon. Weather Rev., 140, 1385-1403, doi:10.1175/mwr-d-11-00112.1, 2011.

Rutledge, S. A. and Hobbs, P. V.: The mesoscale and microscale structure and organization of clouds and precipitation in Midlatitude cyclones, XII: A diagnostic modeling study of precipitation development in narrow cold-frontal rainbands, J. Atmos. Sci., 41, 2949-2972, doi:10.1175/15200469(1984)041<2949:tmamsa>2.0.co;2, 1984.

Ruzanski, E. and Chandrasekar, V.: An investigation of the shortterm predictability of precipitation using high-resolution composite radar observations, J. Appl. Meteorol. Clim., 51, 912-925, doi:10.1175/jamc-d-11-069.1, 2012.

Ruzanski, E., Chandrasekar, V., and Wang, Y.: The CASA nowcasting system, J. Atmos. Ocean. Tech., 28, 640-655, doi:10.1175/2011jtecha1496.1, 2011.

Ryzhkov, A. V., Schuur, T. J., Burgess, D. W., and Zrnić, D. S.: Polarimetric tornado detection, J. Appl. Meteorol., 44, 557-570, doi:10.1175/jam2235.1, 2005.

Ryzhkov, A. V., Giangrande, S., Khain, A., Pinsky, M., and Pokrovsky, A.: Polarimetric characteristics of melting hail at $\mathrm{S}$ and $\mathrm{C}$ bands, available online at: http://ams.confex.com/ams/ pdfpapers/155571.pdf, Proc. 34th Conf. on Radar Meteorology, Williamsburg, 2009.

Sachidananda, M. and Zrnić, D. S.: $Z_{\mathrm{DR}}$ measurement considerations for a fast scan capability radar, Radio Sci., 20, 907-922, 1985.

Sachidananda, M. and Zrnić, D. S.: Rain rate estimates from differential polarization measurements, J. Atmos. Ocean. Tech., 4, 588-598, 1987.

Sánchez, J. R.: Multi-sensor measurements of raindrop size distribution at NASA Wallops Flight Facility, in: Study of the variability of the rainfall microstructure: a comparision using multisensor measurements, Escola Tècnica Superior d'Enginyers de Camins, Canals i Ports de Barcelona, 22-48, 2006.

Scharfenberg, K. A., Miller, D. J., Schuur, T. J., Schlatter, P. T., Giangrande, S. E., Melnikov, V. M., Burgess, D. W., Andra, D. L., Foster, M. P., and Krause, J. M.: The Joint Polarization Experiment: Polarimetric radar in forecasting and warning decision making, Weather Forecast., 20, 775-788, doi:10.1175/waf881.1, 2005. 
Seed, A. W.: STEPS: an empirical treatment of forecast uncertainty, in: Hydrometeorological Applications of Weather and Climate Modelling: extended abstracts of presentations at the seventeenth annual BMRC Modelling Workshop, 3-6 October 2005, BMRC Research report, edited by: Bureau of Meteorology Research Centre, Australia, 131-137, 2005.

Sugier, J., Tabary, P., Gourley, J., and Fredrich, K.: Evaluation of dual-polarisation technology at C-band for operational weather radar network, OPERA 2, Work Packages 1.4 and 1.5, Deliverable b, http://www.knmi.nl/opera/opera2/ OPERA200605Evaluationofdualpolarizationtechnology.pdf, last access: 15 March 2013, 44 pp., 2006.

Tapiador, F. J., Checa, R., and de Castro, M.: An experiment to measure the spatial variability of rain drop size distribution using sixteen laser disdrometers, Geophys. Res. Lett., 37, L16803, doi:10.1029/2010g1044120, 2010.

Thurai, M., Petersen, W. A., Tokay, A., Schultz, C., and Gatlin, P.: Drop size distribution comparisons between Parsivel and 2-D video disdrometers, Adv. Geosci., 30, 3-9, doi:10.5194/adgeo30-3-2011, 2011.

Thurai, M., Bringi, V. N., Carey, L. D., Gatlin, P., Schultz, E., and Petersen, W. A.: Estimating the accuracy of polarimetric radar-based retrievals of drop-size distribution parameters and rain rate: An application of error variance separation using radar-derived spatial correlations, J. Hydrol., 13, 1066-1079, 10.1175/jhm-d-11-070.1, 2012.

Tokay, A., Petersen, W. A., Gatlin, P., and Wingo, M.: Comparison of raindrop size distribution measurements by collocated disdrometers, J. Atmos. Ocean. Tech., 30, 1672-1690, doi:10.1175/jtech-d-12-00163.1, 2013.
Vulpiani, G., Montopoli, M., Passeri, L. D., Gioia, A. G., Giordano, P., and Marzano, F. S.: On the use of dual-polarized C-band radar for operational rainfall retrieval in mountainous areas, J. Appl. Meteorol. Clim., 51, 405-425, doi:10.1175/jamc-d-10-05024.1, 2012.

White, A. B., Gottas, D. J., Strem, E. T., Ralph, M., and Neiman, P. J.: An automated brightband height detection algorithm for use with Doppler radar spectral moments, J. Atmos. Ocean. Tech., 19, 687-697, 2002.

Wilson, J. W., Ebert, E. E., Saxen, T. R., Roberts, R. D., Mueller, C. K., Sleigh, M., Pierce, C. E., and Seed, A.: Sydney 2000 forecast demonstration project: Convective storm nowcasting, Weather Forecast., 19, 131-150, doi:10.1175/15200434(2004)019<0131:sfdpcs>2.0.co;2, 2004.

Yamauchi, H., Adachi, A., Kobayashi, T., Inoue, H., Onogi, S., Yamada, A., and Iizuka, H.: Validation of optical disdrometers by comparing with weighing precipitation gauge and tipping bucket rain gauge, Autumn meeting of Meteor. Soc. of Japan, Fukuoka, 2009.

Yamauchi, H., Adachi, A., Suzuki, O., and Kobayashi, T.: Precipitation estimate of a heavy rain event using a C-band solid-state polarimetric radar, 7th European Conf. on Radar in Meteorology and Hydrology, Toulouse, France, 2012.

Zrnić, D. S., Keenan, T. D., Carey, L. D., and May, P.: Sensitivity analysis of polarimetric variables at a $5-\mathrm{cm}$ wavelength in rain, J. Appl. Meteorol., 39, 1514-1526, doi:10.1175/15200450(2000)039<1514:saopva>2.0.co;2, 2000. 